\title{
Holocene Core Logs and Site Statistics for Modern Patch-Reef Cores: Biscayne National Park, Florida
}

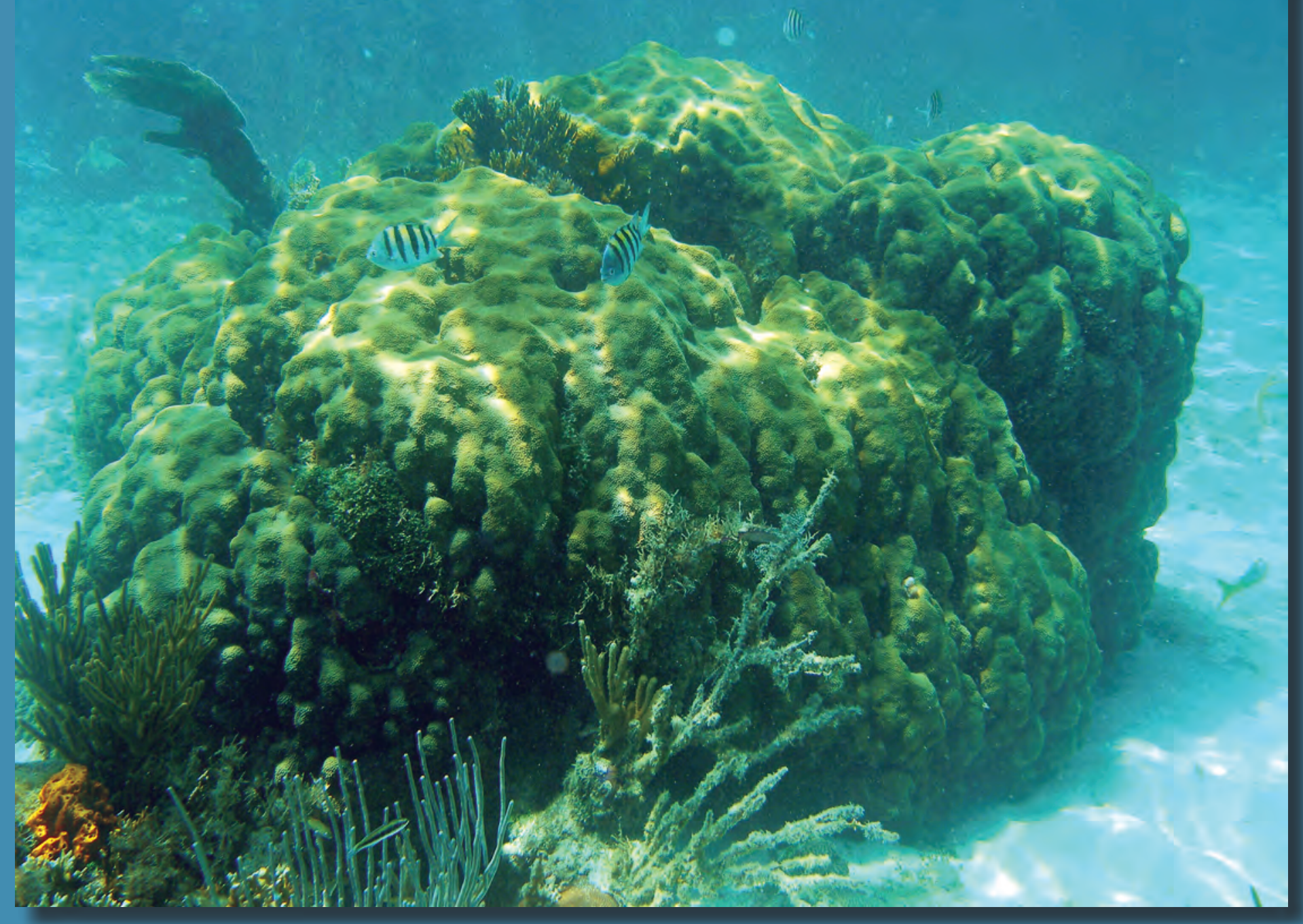

Open-File Report 2009-1246 



\section{Holocene Core Logs and Site Statistics for Modern Patch-Reef Cores: Biscayne National Park, Florida}

By Christopher D. Reich, T. Don Hickey, Kristine L. DeLong, Richard Z. Poore, and John C. Brock

Open-File Report 2009-1246 


\title{
U.S. Department of the Interior \\ KEN SALAZAR, Secretary \\ U.S. Geological Survey \\ Marcia K. McNutt, Director
}

\section{U.S. Geological Survey, Reston, Virginia: 2009}

\author{
For more information on the USGS — the Federal source for science about the Earth, its natural and living resources, \\ natural hazards, and the environment, visit http://www.usgs.gov or call 1-888-ASK-USGS \\ For an overview of USGS information products, including maps, imagery, and publications, \\ visit http://www.usgs.gov/pubprod \\ To order this and other USGS information products, visit http://store.usgs.gov
}

\begin{abstract}
Any use of trade, product, or firm names is for descriptive purposes only and does not imply endorsement by the U.S. Government.

Although this report is in the public domain, permission must be secured from the individual copyright owners to reproduce any copyrighted materials contained within this report.
\end{abstract}

Suggested citation:

Reich, C.D., Hickey, T.D., DeLong, K.L., Poore, R.Z., and Brock, J.C., 2009, Holocene core logs and site statistics for modern patch-reef cores_Biscayne National Park, Florida: U.S. Geological Survey Open-File Report 2009-1246, 26 p.

All photographs are from U.S. Geological Survey files. 


\section{Contents}

Introduction.
Methods.
Coring
Results and Summary
Coral Cores
Wireline Cores
Acknowledgments Diffraction and Carbon-14 Analyses
References Cited.
Appendix A. Photographs of coral heads after drilling, Biscayne National Park
Appendix B. Core logs and photographs of the cores at each location,
Biscayne National Park

\section{Figures}

1. Annotated Landsat 7 false-color thematic mapper (1999) image denoting wireline

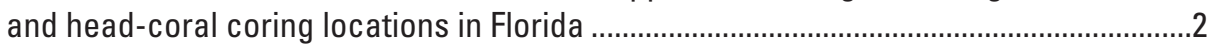

2. High-resolution Lidar bathymetry and location of sites drilled near Alina's Reef ..............3

3. Photograph of a SCUBA diver using the underwater coral coring drill .............................4

4. Photograph of tripod and underwater wireline coring system...........................................5

5. X-ray diffraction plot showing results of coral powder from Holocene sample

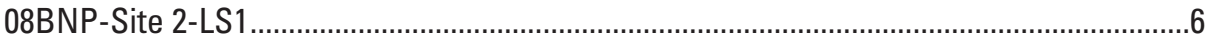

\section{Tables}

1. Information on head coral cores collected in Biscayne National Park in May 2008 .........3

2. Information on Holocene wireline cores collected in Biscayne National Park in May 2008 ...........................................................................................................

3. Radiocarbon ages and corrected ${ }^{14} \mathrm{C}$ dates for Holocene wireline core samples from Biscayne National Park 


\section{Conversion Factors}

\begin{tabular}{lcl}
\multicolumn{1}{c}{ Inch/Pound to SI } & \multicolumn{1}{c}{ Multiply } & \multicolumn{1}{c}{ To obtain } \\
\hline & Length & \\
\hline inch (in.) & 2.54 & centimeter $(\mathrm{cm})$ \\
foot (ft) & 0.3048 & meter $(\mathrm{m})$ \\
mile (mi) & 1.609 & kilometer $(\mathrm{km})$ \\
mile, nautical (nmi) & 1.852 & kilometer $(\mathrm{km})$ \\
& Area & \\
acre & 4,047 & square meter $\left(\mathrm{m}^{2}\right)$ \\
square foot ( $\left.\mathrm{ft}^{2}\right)$ & 929.0 & square centimeter $\left(\mathrm{cm}^{2}\right)$ \\
square inch (in $\left.{ }^{2}\right)$ & 6.452 & square centimeter $\left(\mathrm{cm}^{2}\right)$ \\
section $\left(640 \mathrm{acres}^{2}\right.$ or 1 square mile) & 259.0 & square hectometer $\left(\mathrm{hm}^{2}\right)$ \\
square mile (mi $\left.{ }^{2}\right)$ & 2.590 & square kilometer $\left(\mathrm{km}^{2}\right)$ \\
mile per hour (mi/h) & 1.609 & kilometer per hour $\left(\mathrm{km}^{2} / \mathrm{h}\right)$ \\
\hline
\end{tabular}

SI to Inch/Pound

\begin{tabular}{lcl}
\hline \multicolumn{1}{c}{ Multiply } & \multicolumn{1}{c}{ By } & \multicolumn{1}{c}{ To obtain } \\
\hline centimeter $(\mathrm{cm})$ & Length & \\
meter $(\mathrm{m})$ & 0.3937 & centimeter $(\mathrm{cm})$ \\
kilometer $(\mathrm{km})$ & 3.281 & foot $(\mathrm{ft})$ \\
kilometer $(\mathrm{km})$ & 0.6214 & mile $(\mathrm{mi})$ \\
& 0.5400 & mile, nautical $(\mathrm{nmi})$ \\
\hline square kilometer $\left(\mathrm{km}^{2}\right)$ & Area & \\
\hline
\end{tabular}

Temperature in degrees Celsius $\left({ }^{\circ} \mathrm{C}\right)$ may be converted to degrees Fahrenheit $\left({ }^{\circ} \mathrm{F}\right)$ as follows:

$$
{ }^{\circ} \mathrm{F}=\left(1.8 \times{ }^{\circ} \mathrm{C}\right)+32
$$

Temperature in degrees Fahrenheit $\left({ }^{\circ} \mathrm{F}\right)$ may be converted to degrees Celsius $\left({ }^{\circ} \mathrm{C}\right)$ as follows:

$$
{ }^{\circ} \mathrm{C}=\left({ }^{\circ} \mathrm{F}-32\right) / 1.8
$$

Vertical coordinate information is referenced to the North American Vertical Datum of 1988 (NAVD 88). 


\title{
Holocene Core Logs and Site Statistics for Modern Patch-Reef Cores: Biscayne National Park, Florida
}

\author{
By Christopher D. Reich, T. Don Hickey, Kristine L. DeLong, Richard Z. Poore, and John C. Brock
}

\section{Introduction}

The bedrock in Biscayne National Park (BNP), a 1,730-square kilometer $\left(\mathrm{km}^{2}\right)$ region off southeast Florida, consists of Pleistocene (1.8 million years ago (Ma) to $10,000$ years ago $(\mathrm{ka}))$ and Holocene (10 ka to present) carbonate rocks (Enos and Perkins, 1977; Halley and others, 1997; Multer and others, 2002). Most of the surficial limestone in BNP, including the islands of the Florida Keys, was formed at $\sim 125 \mathrm{ka}$ during the highstand of marine oxygen-isotope substage $5 \mathrm{e}$, when sea level was approximately 6 meters (m) higher than today (Chappell and Shackleton, 1986; Multer and others, 2002; Lidz and others, 2003; Siddall and others, 2003; Balsillie and Donoghue, 2004). During the substage-5e regression, the entire Florida Platform became exposed. Subaerial exposure lasted for approximately 115,000 years (kyr), which resulted in erosion and enhancement of karst-like features (Lidz and others, 2006). As the Holocene transgression began to flood the Florida shelf $\sim 7$ to $6 \mathrm{ka}$, the bedrock depression under Biscayne Bay began to flood, and Holocene coral and reef debris laid the foundation for the present reef system (Enos and Perkins, 1977; Lighty and others, 1982; Toscano and Macintyre, 2003; Lidz and others, 2006).

More than 3,000 patch reefs exist within the BNP boundary. Most contain hermatypic corals of various species such as those belonging to Montastrea, Diploria, Siderastrea, Porites, Acropora, and Agaricia. Patch reefs within BNP have two morphologies: pinnacle and flat top. Experimental Advanced Airborne Research Lidar (EAARL) data collected along the offshore BNP coral reef tract show that these two morphologies are clearly defined both in the high-resolution bathymetry maps produced by the Lidar data and by statistical analyses of the Lidar dataset (Brock and others, 2008). Brock and others (2008) also show that the pinnacle patch reefs are deeper than the more shallow, broad, and flat patch reefs. The control for these two patch-reef morphologies is unclear; however, their shapes may be due to a slightly lowered sea level or a stillstand in the middle-Holocene around $4 \mathrm{ka}$ that caused erosion of the shallower reefs and allowed the deeper reefs to remain unaffected. Lidz and others (2006) have suggested a stillstand around 4 ka that carved a 2.5-kilometer $(\mathrm{km})$-wide nearshore rock ledge into the seaward side of every island in the Florida Keys.

The objectives of this study were to sample living corals to understand the more recent ( $<200$ years) changes in climate and environmental conditions of the area and to investigate the Holocene (in this case, $<8,000$ years in the Florida Keys) depositional history at progressively deeper patch-reef sites. This report provides statistics for the cores and core sites and a basic lithologic description of these Holocene cores.

\section{Methods}

\section{Coring}

Core samples were obtained from the carbonate platform and head corals in BNP using the U.S. Geological Survey (USGS) rotary hydraulic coring system (Macintyre, 1975; Shinn and others, 1994; Reich and others, 2006). Holocene wireline (WL) cores were collected at four locations, and head coral (HC) samples were collected at three locations (figs. 1 and 2; tables 1 and 2). Drilling equipment consisted of a hydraulic-powered submersible drill, a 4-inch (in.)-diameter by 24 -in.-long core barrel with surface-set diamond bit, and a hydraulic-power unit operated from the surface supply boat. A tripod was used in the shallow water to suspend the hydraulic drill and to help maintain vertical position during coring (fig. 3). Corals were drilled where the growth axis was presumed to be vertical. In many cases, the core barrel had to be inserted multiple times to collect the full length of coral growth on top of bedrock. After core extraction from the coral, the cores were placed on an onboard drying table prior to being wrapped in plastic and secured for travel. Coral cores were then placed in wood boxes and archived at the USGS-St. Petersburg, FL, facility. A pre-cast concrete plug was inserted into the 4-in. open hole left in the head coral. The plug provides a substratum that will be overgrown by the coral. 


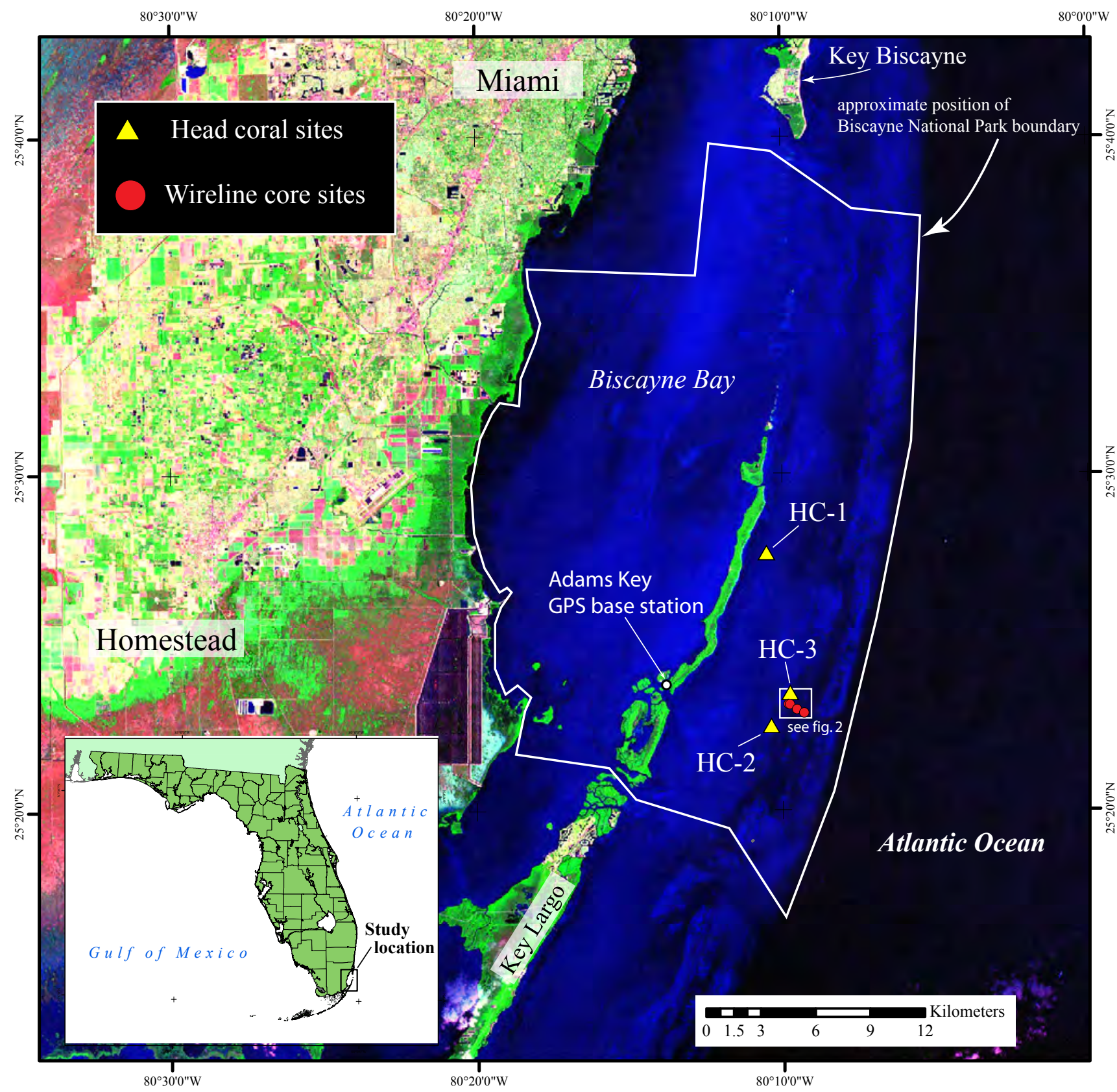

Figure 1. Annotated Landsat 7 false-color thematic mapper (1999) image denoting wireline (WL; circle) and head-coral (HC; triangle) coring locations in Florida. Inset shows Biscayne National Park (BNP) study area. 


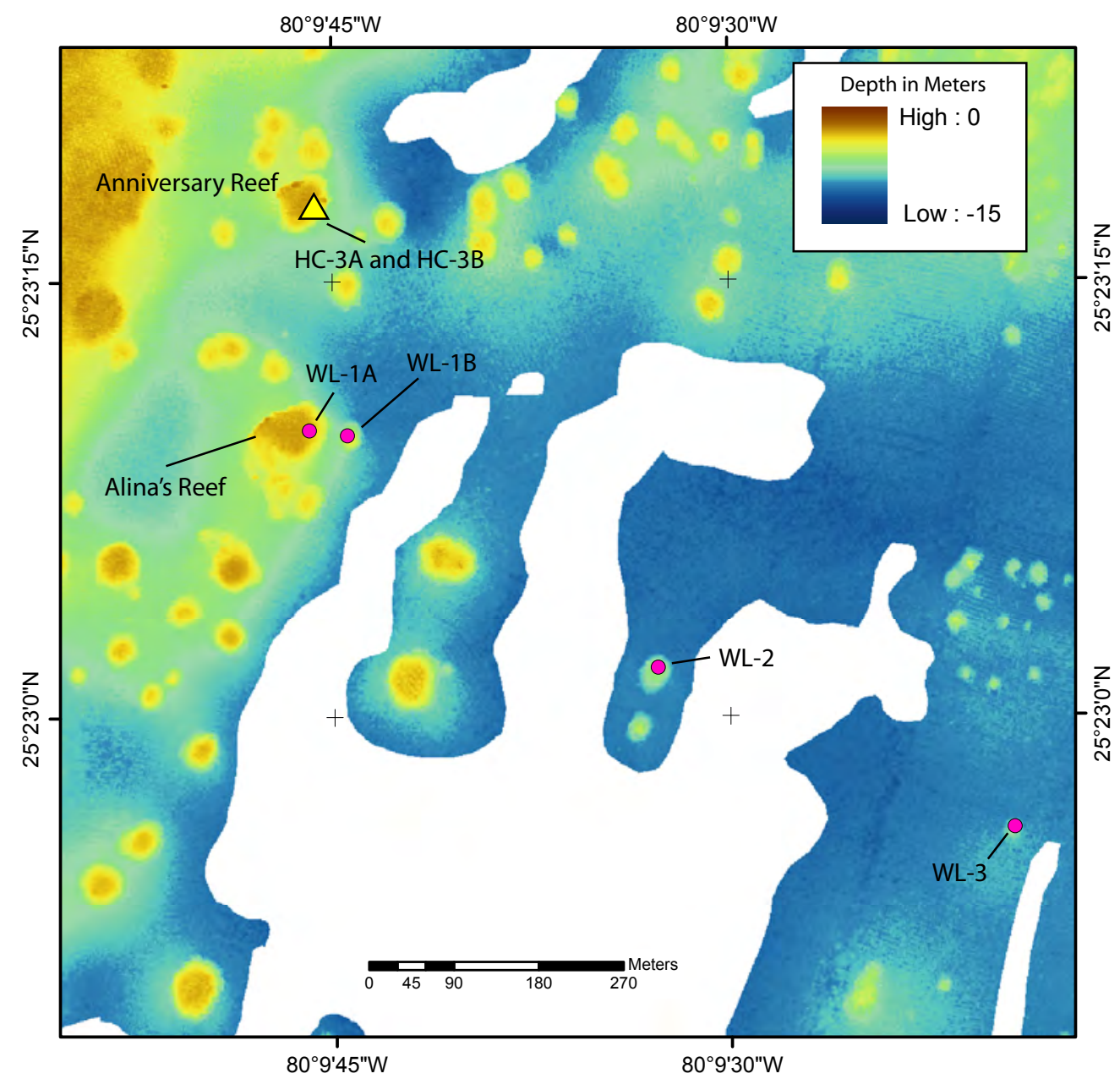

Figure 2. High-resolution Lidar bathymetry and location of sites drilled near Alina's Reef. Circles represent wireline (WL) core sites that were drilled to the top of the Pleistocene surface. Triangle at Anniversary Reef is the site where Diploria strigosa and Montastrea faveolata head corals (HC-3A and $\mathrm{HC}-3 \mathrm{~B}$, respectively) were cored. White area indicates that no Lidar data are available. Note that shallow sites near Alina's Reef and Anniversary Reef are broad and flat, and sites farther offshore are pinnacle shaped. See appendix B for cores and core logs from Sites WL-1A, WL-1B, WL-2, and WL-3.

Table 1. Information on head coral (HC) cores collected in Biscayne National Park (BNP) in May 2008.

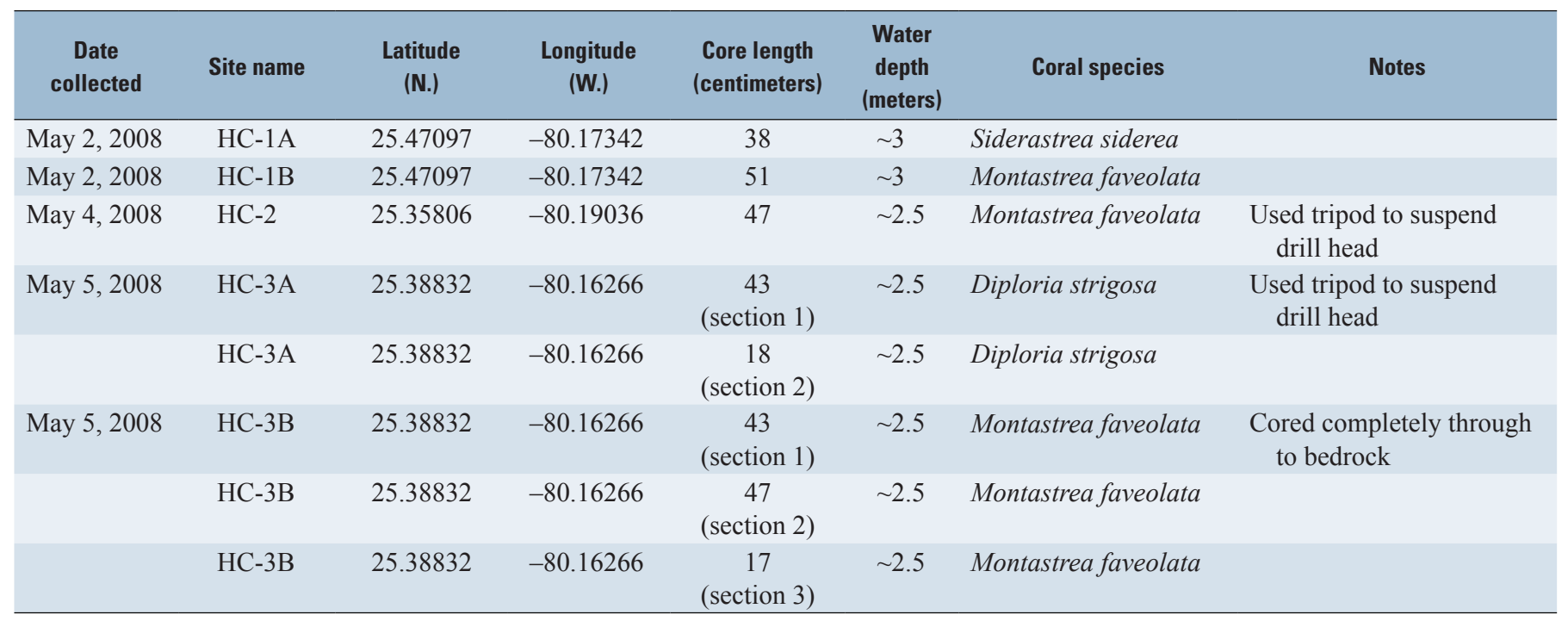


Table 2. Information on Holocene wireline (WL) cores collected in Biscayne National Park (BNP) in May 2008.

[NAVD 88, North American Vertical Datum of 1988]

\begin{tabular}{lllcccc}
\hline $\begin{array}{c}\text { Date } \\
\text { collected }\end{array}$ & Site name & $\begin{array}{c}\text { Latitude } \\
\text { (N.) }\end{array}$ & $\begin{array}{c}\text { Longitude } \\
\text { (W.) }\end{array}$ & $\begin{array}{c}\text { Total depth } \\
\text { drilled } \\
\text { (feet) }\end{array}$ & $\begin{array}{c}\text { Approximate } \\
\text { water depth } \\
\text { (meters) }\end{array}$ & $\begin{array}{c}\text { Seafloor } \\
\text { elevation } \\
\text { (meters NAVD 88) }\end{array}$ \\
\hline May 5-6, 2008 & WL-1A & 25.38617 & -80.16299 & 14.0 & 2.5 & $-2.837^{*}$ \\
May 6-7, 2008 & WL-1B & 25.38603 & -80.16235 & 30.0 & 4.0 & -4.321 \\
May 7-8, 2008 & WL-2 & 25.38380 & -80.15910 & 26.5 & 5.5 & -5.680 \\
May 9, 2008 & WL-3 & 25.38226 & -80.15535 & 30.0 & 6.5 & -6.479 \\
\hline
\end{tabular}

*Approximate depth, located near pre-existing site (see Reich and others, 2006).

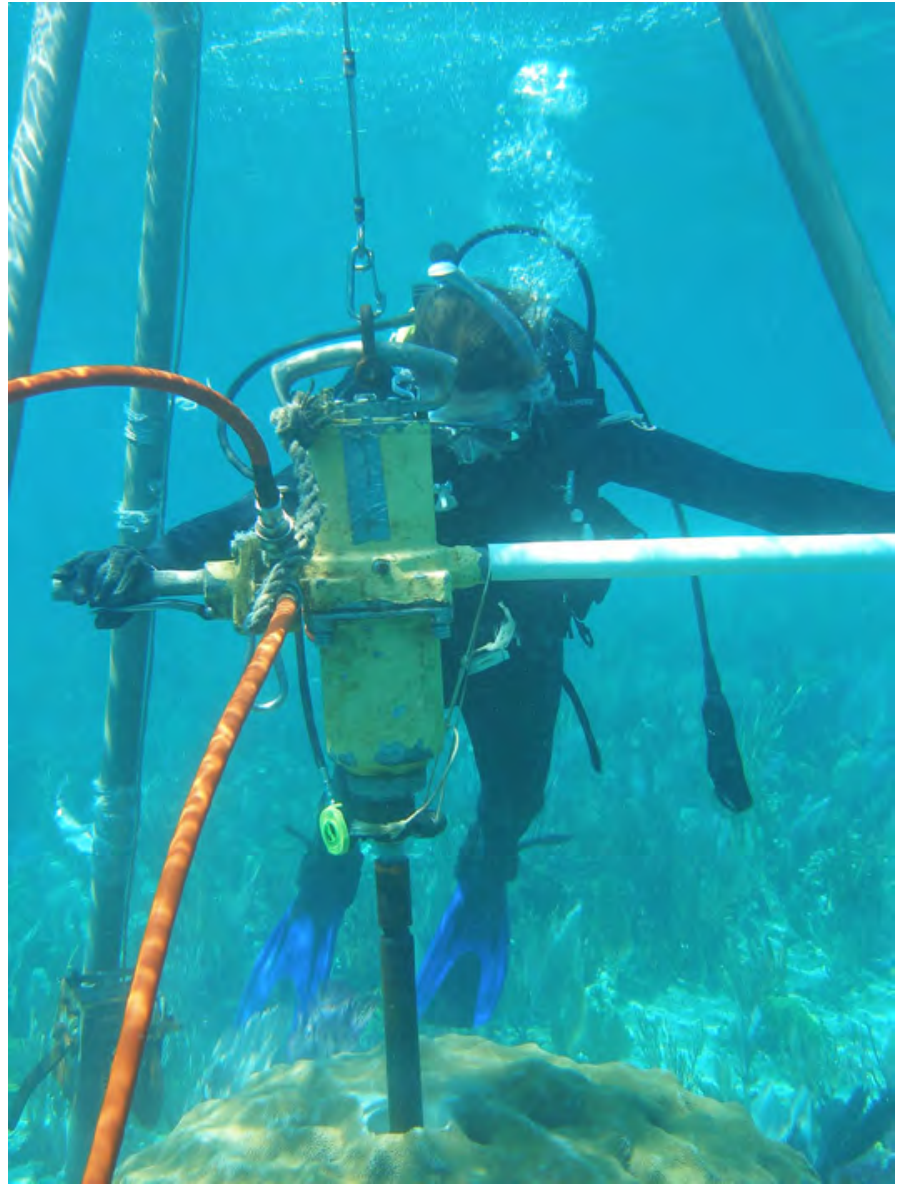

Figure 3. A SCUBA diver using the underwater coral coring drill.
Coring the Holocene seafloor was accomplished using an NQ-2 wireline system (Boart Longyear), a high-speed and low-torque hydraulic motor, and a gear pump that circulated water as drilling fluid (fig. 4). The NQ-2 wireline system contains an inner barrel that retains a 2-in.-diameter core and is extracted at 5 -foot (ft) intervals by using an overshot tool attached to a rope (or wire) that runs through a pulley to a capstan mounted on the tripod. Core barrels are $5 \mathrm{ft}$ long; core extraction was made at those intervals. After extraction, the core barrel with core was taken to the boat, where the core was removed, placed in a wood box, and allowed to air dry before being placed in a cardboard core box for archiving. All cores were eventually archived at the USGS-St. Petersburg facility.

\section{Core Location Elevation Survey}

Proper elevation control for each core was critical for allowing accurate cross-borehole core correlations. To maintain comparable elevations (bathymetry) for the top of each core, a kinematic Global Positioning System (GPS) was used at each site where wireline cores were collected. Ashtech highprecision, dual-frequency GPS receivers coupled with Thales choke-ring antennas were used for this survey. The antenna was mounted to the coring tripod using SECO GPS poles and leveled using a hand level. A base station was established on Adams Key (south end of Elliott Key) over a previously established benchmark (fig. 1). In order to keep GPS errors to a minimum, each site only needed to be occupied for 30 minutes because core locations were less than $15 \mathrm{~km}$ from the base station. All reported root-mean-square errors in position (horizontal and vertical) were less than 3 centimeters $(\mathrm{cm})$. The elevations were corrected to the GEOID03, and results are provided in the North American Vertical Datum of 1988 (NAVD 88) datum (table 2). Sample collection period data were processed using the Novatel GrafNet program. 


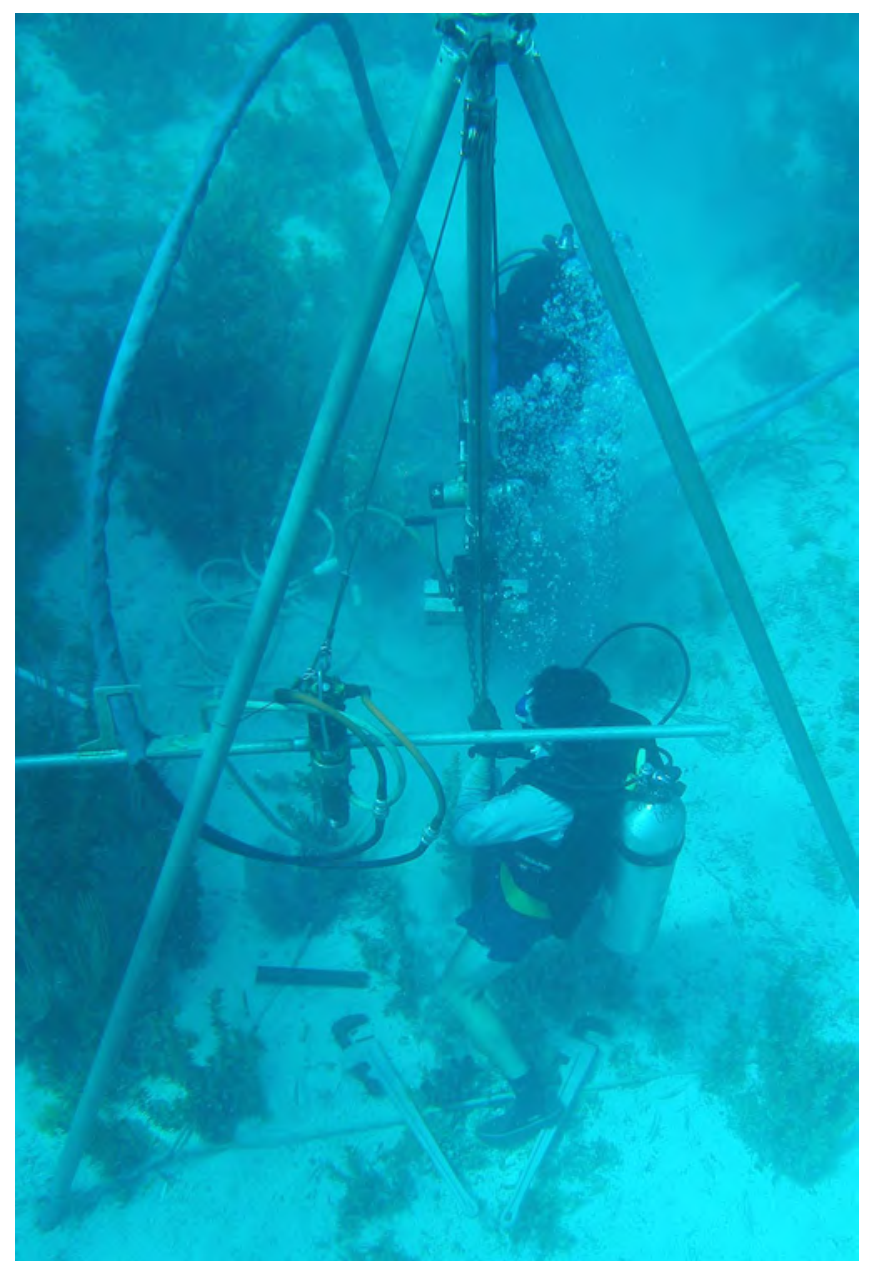

Figure 4. Tripod and underwater wireline coring system. In this photograph, SCUBA divers are extracting the inner barrel that contains the core.

\section{Results and Summary}

\section{Coral Cores}

Coral core data are presented with limited interpretive information because coral samples can be used for paleooceanographic/paleo-climatic analyses yet to be conducted. Studies utilizing BNP coral cores can include coral-growth (extension rates) based on X-radiographs. Subannual to monthly ocean temperature and salinity variability can be determined with trace metal (strontium-to-calcium ratios) and oxygen-isotope $\left(\delta^{18} \mathrm{O}\right)$ analyses of coral powders

Table 1 includes general information on the head coral cores collected for this study, including GPS coordinates, core length, water depth, and coral species. Three coral species were sampled: Siderastrea siderea, Montastrea faveolata, and Diploria strigosa. Photographs of the coral heads after drilling are shown in appendix A.

\section{Wireline Cores}

Wireline cores were described according to the classification of Dunham (1962). Appendix B contains core logs and photographs of the cores at each location. The core logs contain information on texture, fossil remnants, color, sedimentary structures, and core recovery. The core descriptions in appendix B were constructed using RockWare ${ }^{\circledR}$ LogPlot and Adobe ${ }^{\circledR}$ Illustrator ${ }^{\circledR}$ software.

The objective of this part of the study was to collect the Holocene section from a progressively deepening patch-reef transect in BNP. Alina's Reef was selected as the starting point of the coring because of the vast number of research studies conducted at or near that site. Reich and others (2006) core-drilled the reef to install monitoring wells for a waterquality study and provided background data on the geology of the patch reef. The target depth of drilling was the top of the Pleistocene surface, which is identified by a laminated caliche (subaerial-exposure surface). An example of the laminated caliche can be seen just above the 30-ft mark in the core photograph from WL-2 (appendix figure B7). The Holocene sections from each of the patch reefs cored are very similar and consist of massive head corals, cemented reefal debris (grainstone and packstone lithology), and numerous fossils (bryozoa, coralline algae, serpulid worm tubes, molluscan shells, and foraminifera).

\section{X-Ray Diffraction and Carbon-14 Analyses}

Samples from the wireline cores were prepared for X-ray diffraction (XRD) and accelerated mass spectrometry radiocarbon dating (AMS). Samples chosen for XRD and AMS age dating were composed of visually unaltered coral material. Thirteen samples were collected from the four coring sites (table 2), cleaned using an ultra-sonicator in a deionized (DI) water bath, and air dried. A portion of the sample ( 8-10 grams) was placed in a plastic zipper bag for ${ }^{14} \mathrm{C}$ analyses, and another portion ( $\sim 2$ grams) was ground into a powder with a corundum mortar and pestle. Prior to dating, each powder sample was run on a Bruker D4 X-ray diffractometer to verify that the samples were unaltered aragonite (fig. 5). This verification process is necessary prior to submission of carbonate samples for ${ }^{14} \mathrm{C}$ age dating because the presence of calcite can result in ambiguities and introduce noise in the precision of age dating using ${ }^{14} \mathrm{C}$ analytical methods. The coral samples were shipped to the USGS radiocarbon dating laboratory in Reston, VA. Age dates and depths from the radiocarbon analyses are presented in table 3. Ages were determined at the Center for Accelerator Mass Spectrometry (CAMS), Lawrence Livermore National Laboratory, Livermore, CA. 


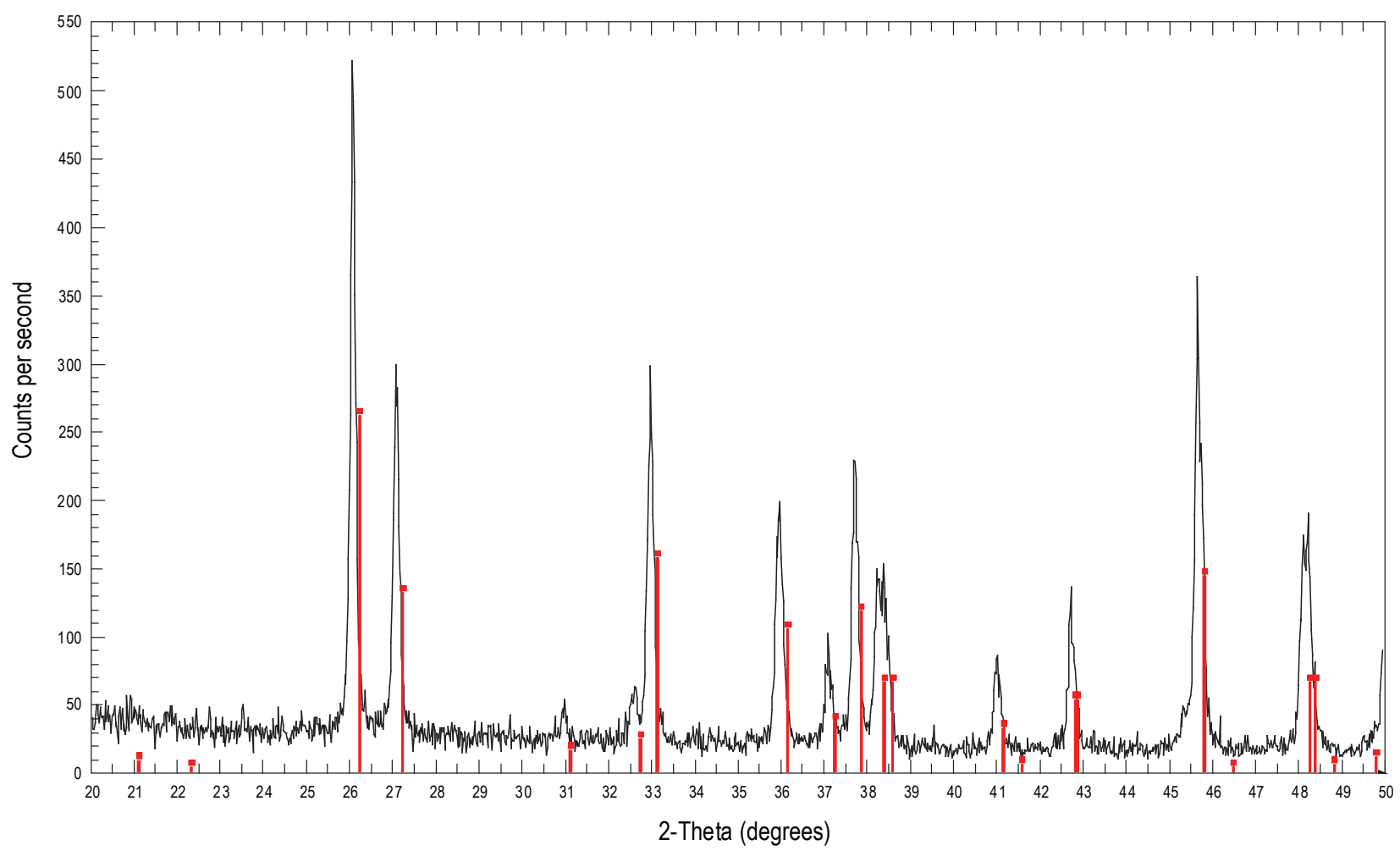

Figure 5. X-ray diffraction (XRD) plot showing results of coral powder (black line) from Holocene sample 08BNP-Site 2-LS1. Sample is nearly 100 percent aragonite, as shown by the red marker lines (aragonite standard peaks).

Table 3. Radiocarbon ages and corrected ${ }^{14} \mathrm{C}$ dates for Holocene wireline core samples from Biscayne National Park.

[In all cases, material dated was fossilized coral. Sample ID corresponds to site and sample number (for example, 08BNP-Site1A-LS1 represents site WL-1A and limestone sample number 1) and is also denoted in appendix B lithologic description logs. NAVD 88, North American Vertical Datum of $1988 ; \pm$, plus or minus; $\sigma, 1$ standard deviation]

\begin{tabular}{|c|c|c|c|c|c|c|c|c|c|}
\hline \multirow{2}{*}{ Sample ID } & \multirow{2}{*}{ Lab ID } & \multirow{2}{*}{$\begin{array}{c}\text { Sample } \\
\text { depth } \\
\text { (feet below } \\
\text { sea floor) }\end{array}$} & \multirow{2}{*}{$\begin{array}{c}\text { Depth } \\
\text { (meters } \\
\text { NAVD 88) }\end{array}$} & \multicolumn{2}{|c|}{$\begin{array}{c}\text { Radiocarbon age } \\
\text { and error }\end{array}$} & \multicolumn{4}{|c|}{ Calibrated age (cal yr BP)† } \\
\hline & & & & ${ }^{14} \mathrm{C}$ age & \pm & median & from & to & $\sigma$ \\
\hline 08BNP-Site1A-LS1 & WW7188 & 1 & -3.142 & 4530 & 35 & 4736 & 4818 & 4624 & 54 \\
\hline 08BNP-Site 1A-LS2 & WW7189 & 4.5 & -4.209 & 4890 & 35 & 5216 & 5294 & 5067 & 64 \\
\hline 08BNP- Site 1A-LS3 & WW7190 & 9 & -5.580 & 5130 & 35 & 5504 & 5577 & 5434 & 41 \\
\hline 08BNP- Site 1A-LS4 & WW7191 & 11 & -6.190 & 5185 & 35 & 5548 & 5602 & 5467 & 37 \\
\hline 08BNP- Site 1B-LS1 & WW7192 & 5 & -5.845 & 4160 & 35 & 4225 & 4346 & 4126 & 56 \\
\hline 08BNP- Site 1B-LS2 & WW7193 & 10 & -7.369 & 4285 & 30 & 4396 & 4490 & 4307 & 42 \\
\hline 08BNP- Site 1B-LS3 & WW7194 & 13 & -8.283 & 5445 & 35 & 5816 & 5895 & 5731 & 45 \\
\hline 08BNP-Site 1B-LS4 & WW7195 & 19 & -10.112 & 5440 & 35 & 5812 & 5890 & 5728 & 45 \\
\hline 08BNP-Site2-LS1 & WW7196 & 0.4 & -5.802 & 4335 & 35 & 4459 & 4546 & 4380 & 41 \\
\hline 08BNP-Site3-LS1 & WW7197 & 0.1 & -6.509 & 5140 & 35 & 5511 & 5577 & 5445 & 38 \\
\hline 08BNP-Site3-LS2 & WW7198 & 7 & -8.613 & 5625 & 40 & 6010 & 6150 & 5915 & 57 \\
\hline 08BNP-Site3-LS3 & WW7199 & 12 & -10.137 & 5975 & 35 & 6375 & 6455 & 6296 & 41 \\
\hline 08BNP-Site3-LS4 & WW7200 & 19.5 & -12.423 & 6065 & 40 & 6478 & 6593 & 6391 & 51 \\
\hline
\end{tabular}

$\dagger$ Calibrated ages obtained using OxCal v. 4.1 (Bronk, 1994) and marine reservoir correction value of 405+18 (cal yr BP=calibrated years before present (1950)). 


\section{Acknowledgments}

We thank Richard Curry at Biscayne National Park for access to the park, permission to core, and on-site logistical support. Thanks to Jordan Sanford and B.J. Reynolds of the USGS and Michèle LaVigne of Rutgers University for assistance in the collection of core samples. Appreciation is extended to John Haines and the USGS Coastal and Marine Geology Program for continued funding support. We also thank John Lisle, Ilsa Kuffner, Barbara Lidz, and John Watson for their comments and reviews.

\section{References Cited}

Balsillie, J.H., and Donoghue, J.F., 2004, High resolution sealevel history for the Gulf of Mexico since the last glacial maximum: Florida Geological Survey, Report of Investigations Number 103, Tallahassee, Florida, 66 p.

Brock, J.C., Palaseanu-Lovejoy, M., Wright, C.W., and Nayegandhi, A., 2008, Patch-reef morphology as a proxy for Holocene sea-level variability, northern Florida Keys, USA: Coral Reefs, v. 27, p. 555-568.

Bronk, R.C., 1994, Analysis of chronological information and radiocarbon calibration - The program OxCal: Archaeological Computing Newsletter, v. 41, p. 11-16.

Chappell, J., and Shackleton, N.J., 1986, Oxygen isotopes and sea level: Nature, v. 324, p. 137-140.

Dunham, R.J., 1962, Classification of carbonate rocks according to depositional texture, in Ham, W.E., ed., Classification of carbonate rocks: American Association of Petroleum Geologists Memoir 1, p. 108-121.

Enos, P., and Perkins, R.D., 1977, Quaternary sedimentation in south Florida: Geological Society of America Memoir 147, $198 \mathrm{p}$.

Halley, R.B., Vacher, H.L., and Shinn, E.A., 1997, Geology and hydrogeology of the Florida Keys, in Vacher, H.L., and Quinn, T.M., eds., Geology and hydrogeology of carbonate islands: New York, Elsevier, p. 217-248.
Lidz, B.H., Reich, C.D., Peterson, R.L., and Shinn, E.A., 2006, New maps, new information - Coral reefs of the Florida Keys: Journal of Coastal Research, v. 22, no. 2, p. 260-282.

Lidz, B.H., Reich, C.D., and Shinn, E.A., 2003, Regional Quaternary submarine geomorphology in the Florida Keys: Bulletin of the Geological Society of America, v. 115, no. 7, p. $845-866$.

Lighty, R.G., Macintyre, I.G., and Stuckenrath, R., 1982, Acropora palmata reef framework-A reliable indicator of sea level in the western Atlantic for the past 10,000 years: Coral Reefs, v. 1, p. 125-130.

Macintyre, I.G., 1975, A diver-operated hydraulic drill for coring submerged substrates: Atoll Research Bulletin, v. 185 , p. $21-26$.

Multer, H.G., Gischler, E., Lundberg, J., Simmons, K.R., and Shinn, E.A., 2002, Key Largo Limestone revisited-Pleistocene shelf-edge facies, Florida Keys, USA: Facies, v. 46, no. 1, p. 229-272.

Reich, C.D., Halley, R.B., Hickey, T.D., and Swarzenski, P.W., 2006, Groundwater characterization and assessment in marine areas of Biscayne National Park, National Park Service. Water Resources Division, Technical Report/NPS/ NRWRD/NRTR-2006/356, 157 p.

Shinn, E.A., Reese, R.S., and Reich, C.D., 1994, Fate and pathways of injection-well effluent in the Florida Keys: U.S. Geological Survey Open-File Report 94-276, 116 p.

Siddall, M., Rohling, E.J., Almogi-Labin, A., Hemleben, C., Meischner, D., Schmelzer, I., and Smeed, D.A., 2003, Sea-level fluctuations during the last glacial cycle: Nature, v. 423, p. $853-858$.

Toscano, M.A., and Macintyre, I.G., 2003, Corrected western Atlantic sea-level curve for the last 11,000 years based on calibrated ${ }^{14} \mathrm{C}$ dates from Acropora palmata framework and intertidal mangrove peat: Coral Reefs, v. 22, p. 257-270. 



\section{Appendixes}

Appendix A. Photographs of coral heads after drilling, Biscayne National Park.

Appendix B. Core logs and photographs of the cores at each location, Biscayne National Park. 


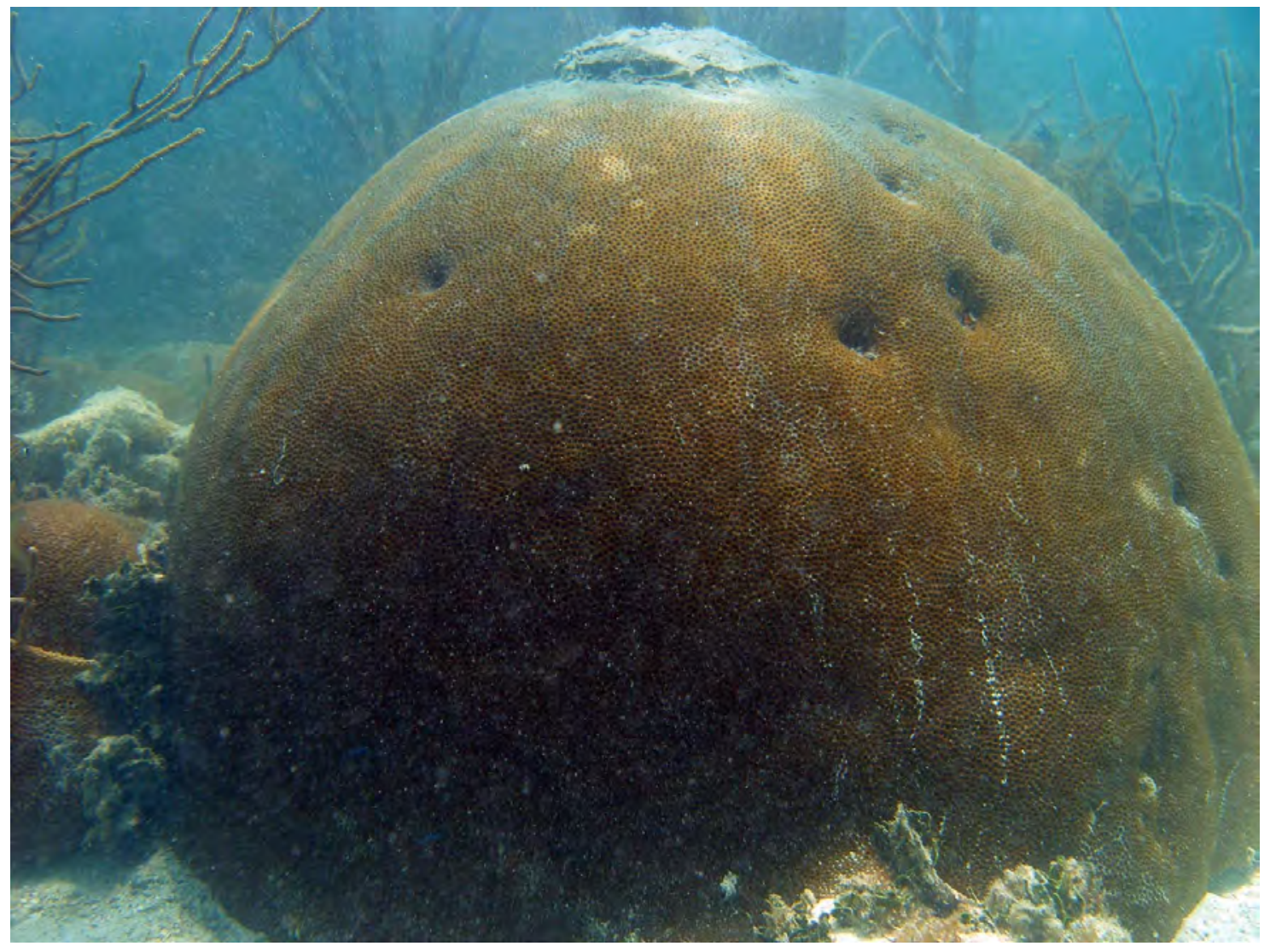

Figure A1. Site HC-1A, Siderastrea siderea. Note cement plug in core hole in top of coral head. 


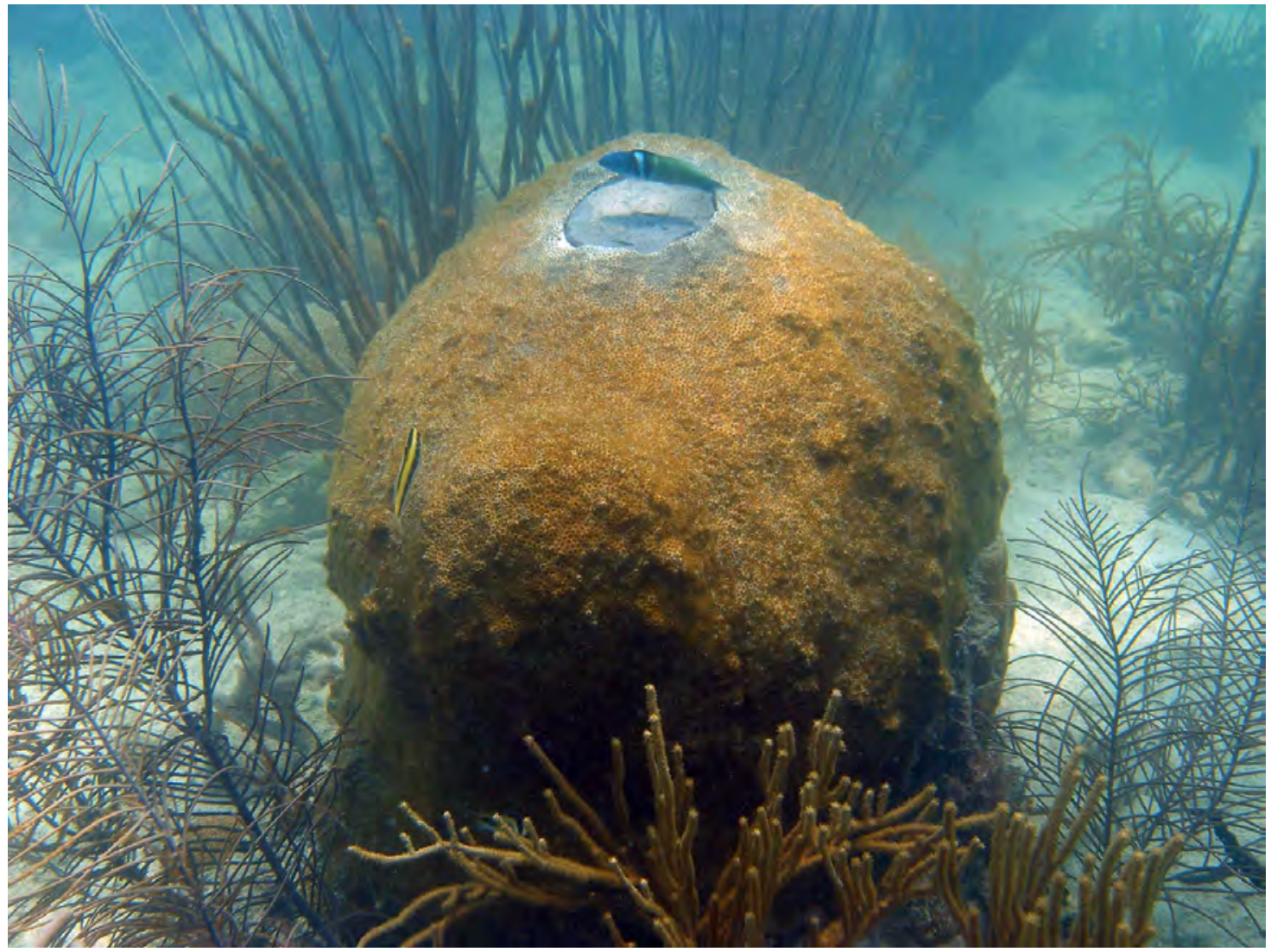

Figure A2. Site HC-1B, Montastrea faveolata. Note cement plug in core hole in top of coral head. 


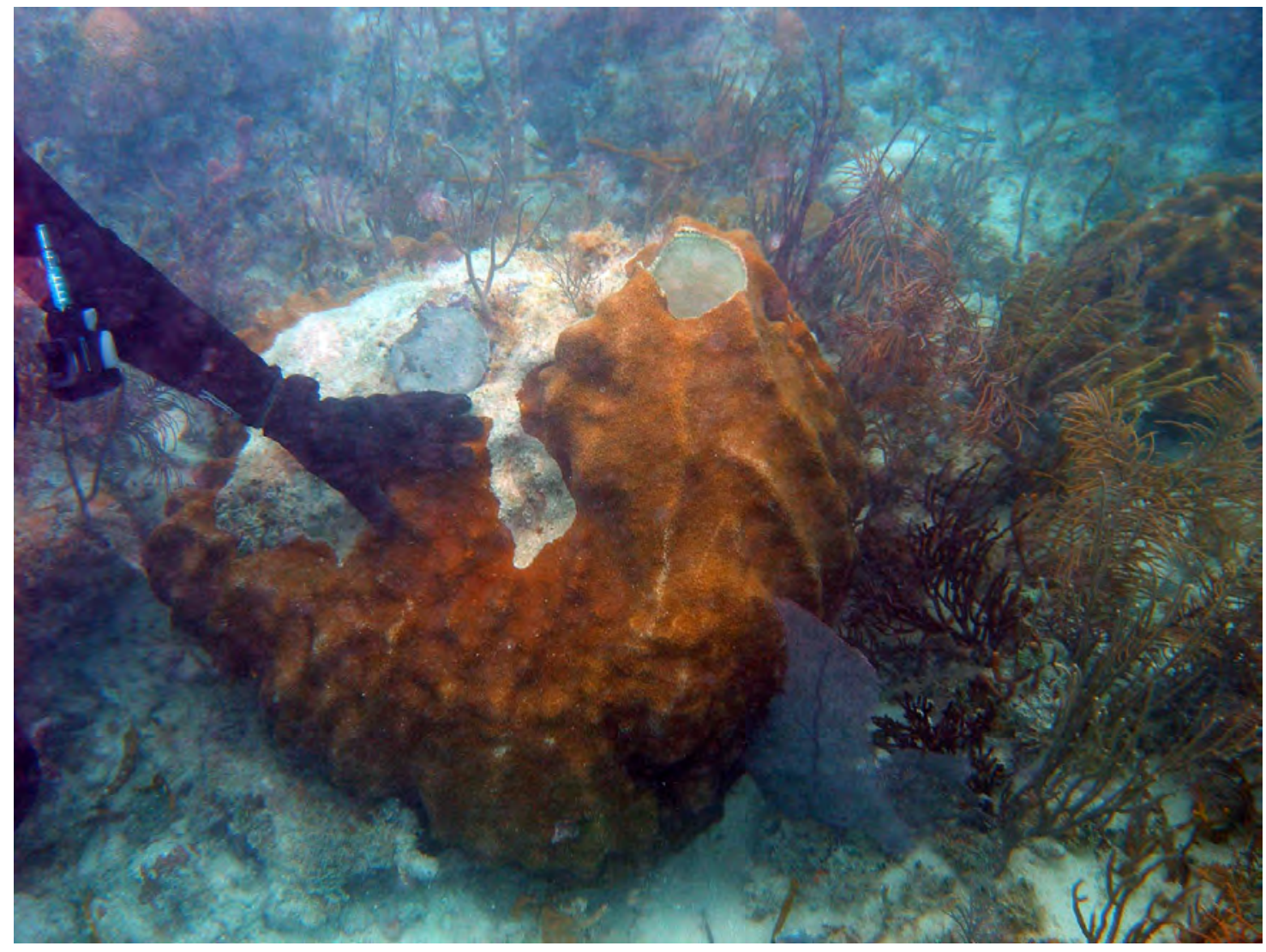

Figure A3. Site HC-2, Montastrea faveolata. Note diver's hand for scale. 


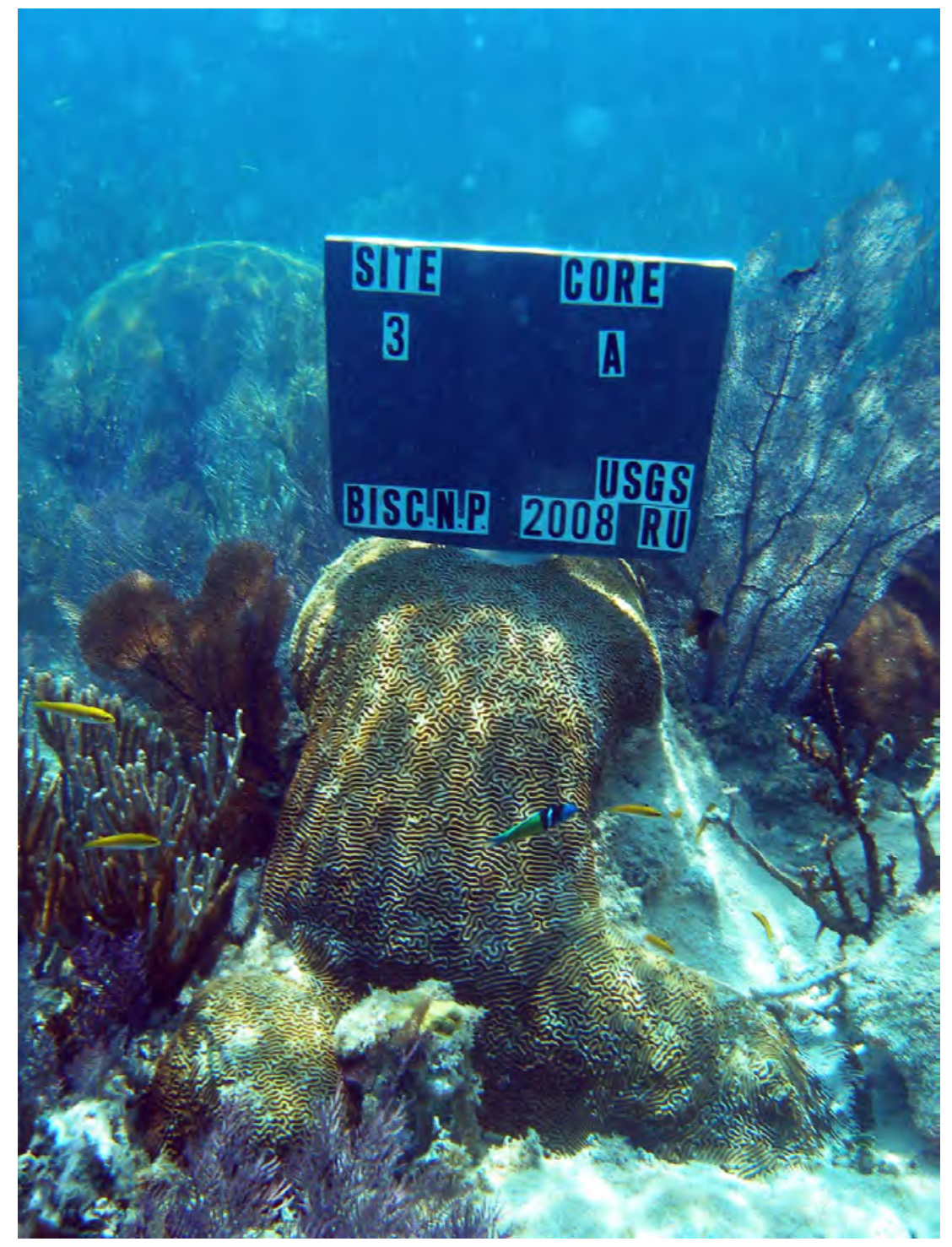

Figure A4. Site HC-3A, Diploria strigosa. Core hole beneath sign has been plugged with cement. 


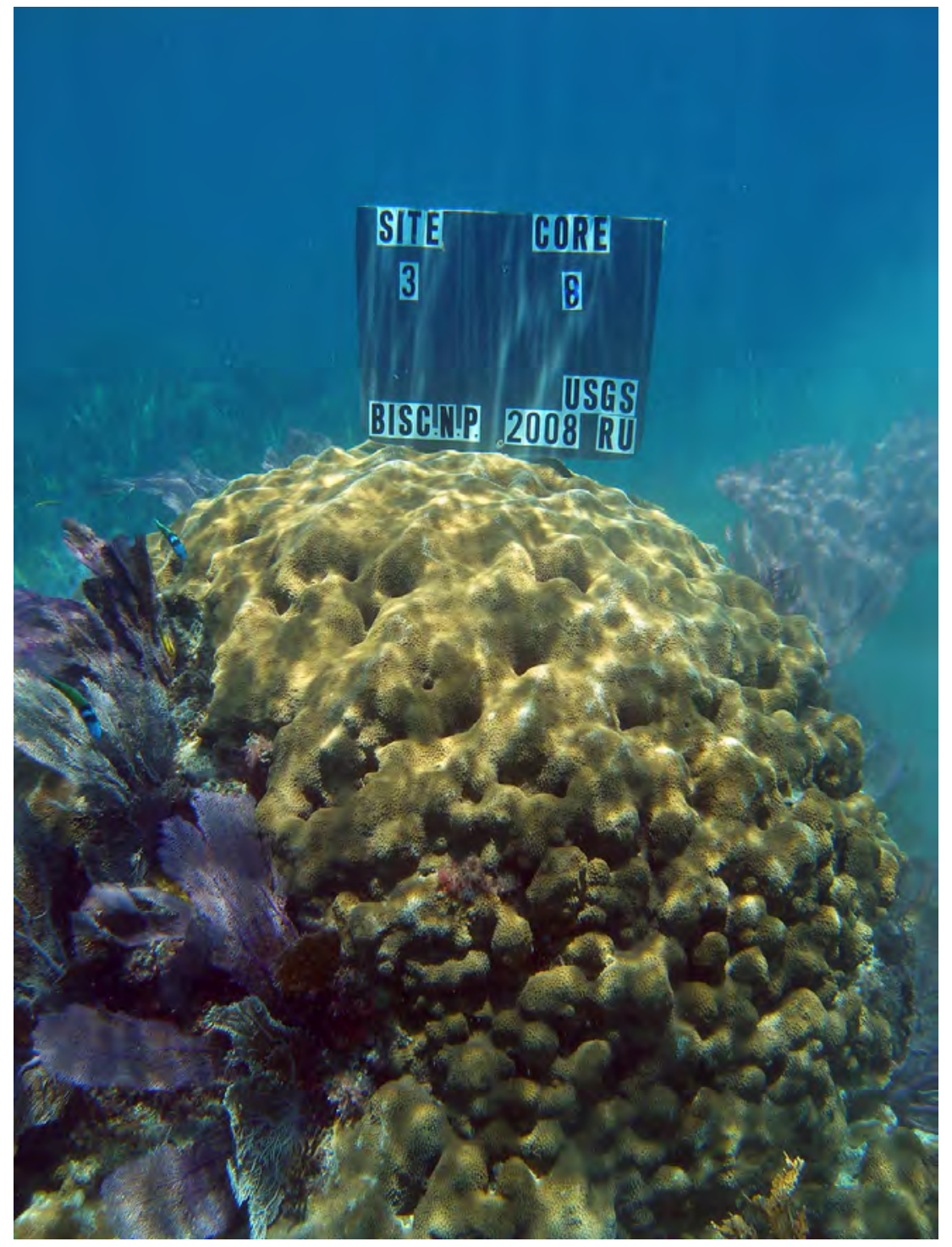

Figure A5. Site HC-3B Montastrea faveolata. Core hole beneath sign has been plugged with cement. 
Classification of Carbonate Rocks According to Depositional Texture (after Dunham, 1962)

\begin{tabular}{|c|c|c|c|c|c|}
\hline \multicolumn{5}{|c|}{ DEPOSITIONAL TEXTURE RECOGNIZABLE } & \multirow{2}{*}{$\begin{array}{l}\text { DEPOSITIONAL TEXTURE } \\
\text { NOT RECOGNIZABLE }\end{array}$} \\
\hline \multicolumn{4}{|c|}{ Original Components not Bound Together During Deposition } & \multirow{5}{*}{\begin{tabular}{|c|} 
Original Components \\
were bound together \\
during deposition... \\
as shown by intergrown \\
skeletal matter, \\
lamination contrary to gravity \\
or sediment-floored cavities that \\
are roofed over by organic matter and \\
are too large to be interstices. \\
Boundstone
\end{tabular}} & \\
\hline \multicolumn{3}{|c|}{$\begin{array}{c}\text { Contains mud } \\
\text { (particles of clay and fine silt size) }\end{array}$} & \multirow{4}{*}{$\begin{array}{l}\text { Lacks mud } \\
\text { and is } \\
\text { grain-supported }\end{array}$} & & \multirow{4}{*}{$\begin{array}{c}\text { Crystalline Carbonate } \\
\text { (Subdivide according to } \\
\text { classifications designed to bear } \\
\text { on physical texture or diagenesis.) }\end{array}$} \\
\hline Mud-su & pported & & & & \\
\hline $\begin{array}{c}\text { Less than } \\
10 \text { percent grains }\end{array}$ & $\begin{array}{c}\text { More than } \\
10 \text { percent grains }\end{array}$ & Grain-supported & & & \\
\hline Mudstone & Wackestone & Packstone & & & \\
\hline
\end{tabular}

Patterns Used in Well Logs and Their Corresponding Lithologies

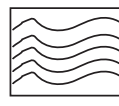

Laminated crust
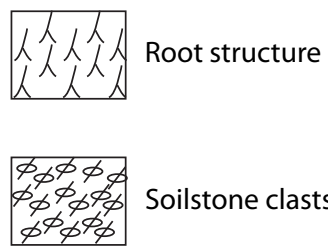

Soilstone clasts

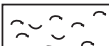

ニュ- Skeletal debris

Head corals

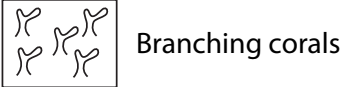

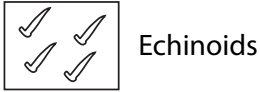

$\# \#$

$\# \# \#$

Bryozoan (Schizoporella)

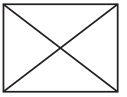

No recovery

$\checkmark \mathcal{Y}$

Oyster \begin{tabular}{|lll}
\hline & 0 & 0 \\
0 & 0 & 0 \\
0 & 0 & 0 \\
0
\end{tabular}

(ㅇ) () (-)

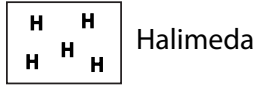

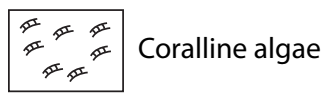

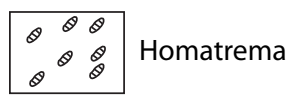

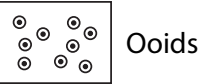

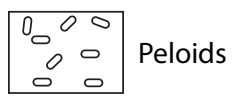

$\because \because \because \because$ Quartz sand

$\int_{\xi}\{$ Burrows

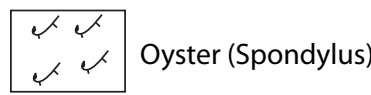

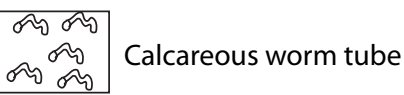

$\varnothing$ in heading of core description denotes porosity (decimal units)

Figure B1. Log legend and lithologic patterns used in appendix B wireline core logs (modified from Dunham, 1962). 


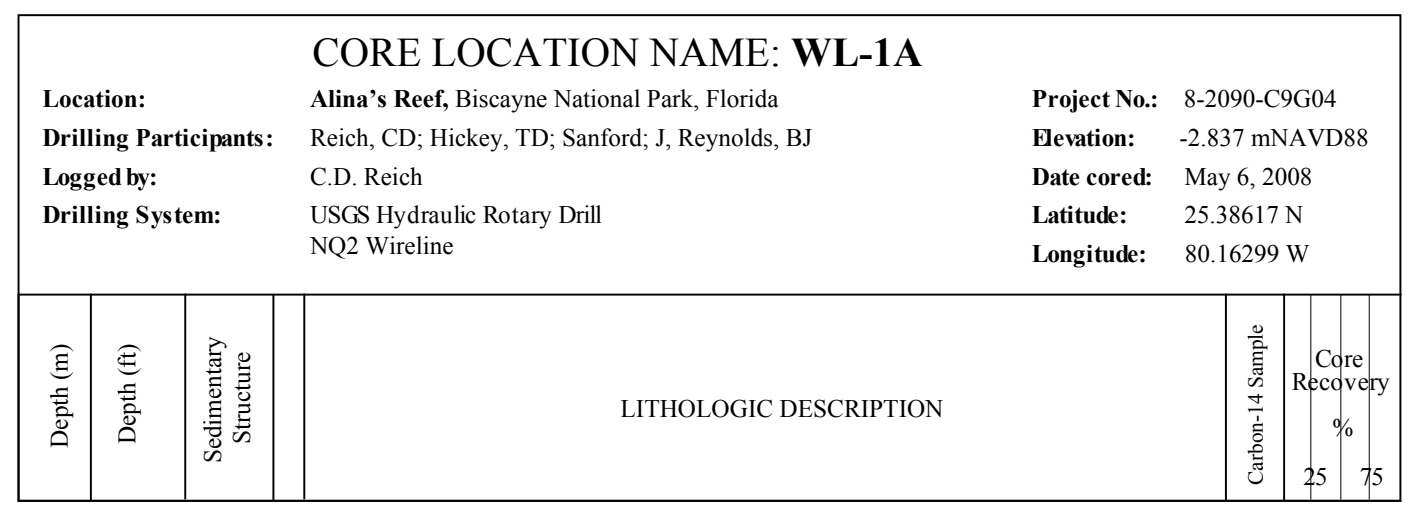

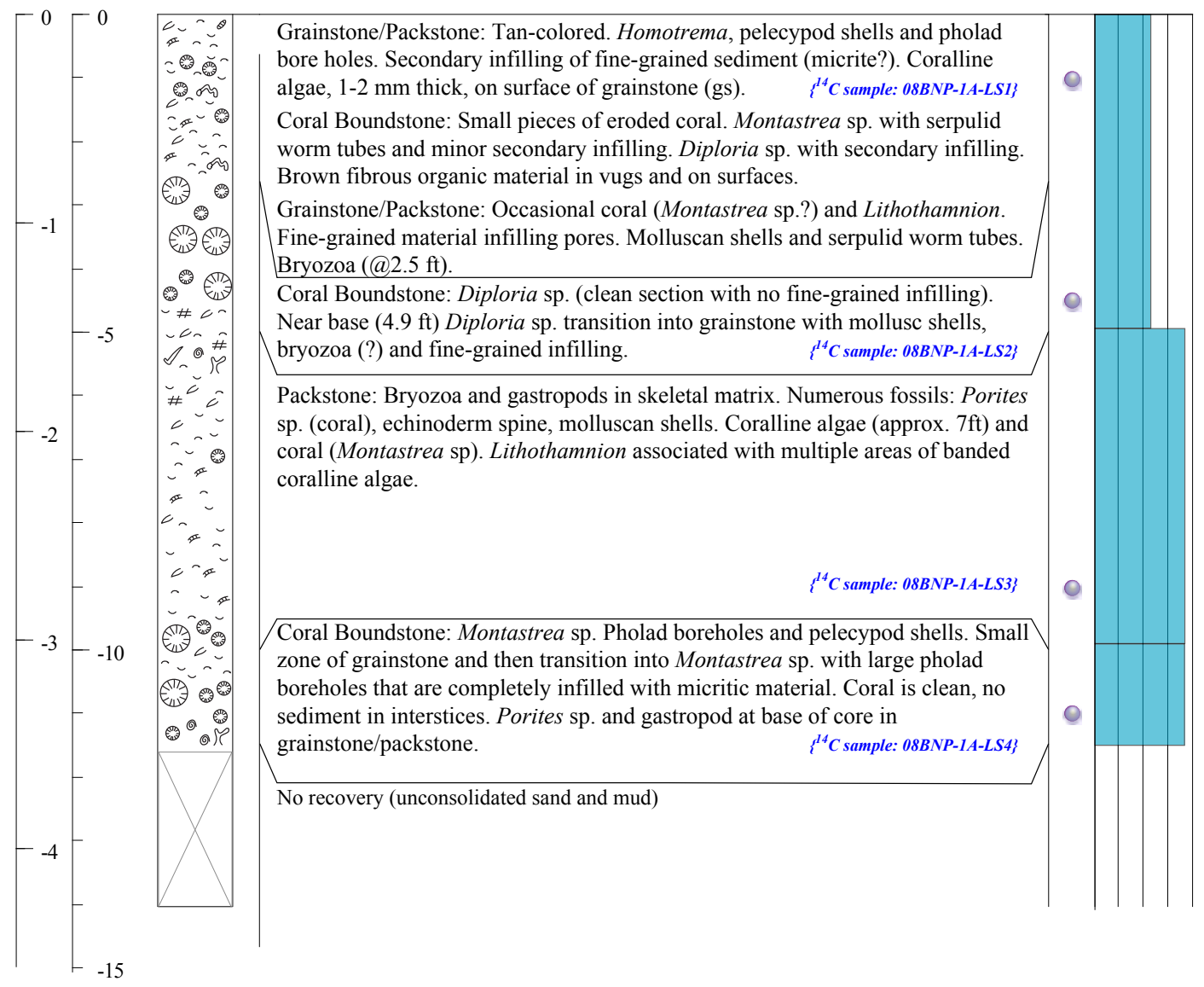

$\begin{array}{ll}\text { science for a changing world } & \begin{array}{l}\text { Company Name: USGS, St. Petersburg } \\ \text { Project Name: } \\ \text { Location: }\end{array} \\ \text { Biscayne National Park, Florida }\end{array}$

Figure B2. Core description for WL-1A. 


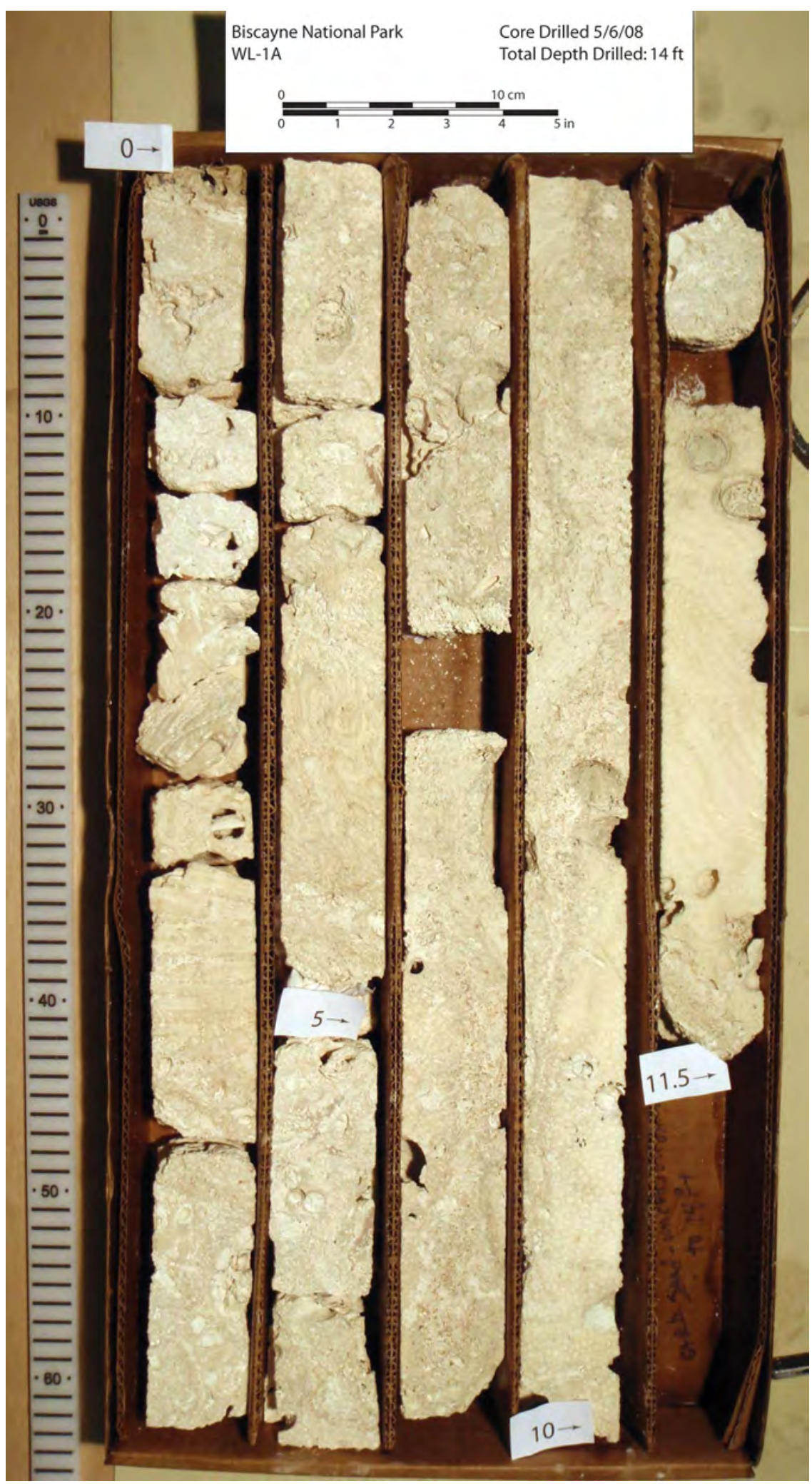

Figure B3. Core collected at WL-1A (0 to $14 \mathrm{ft}$ ). 


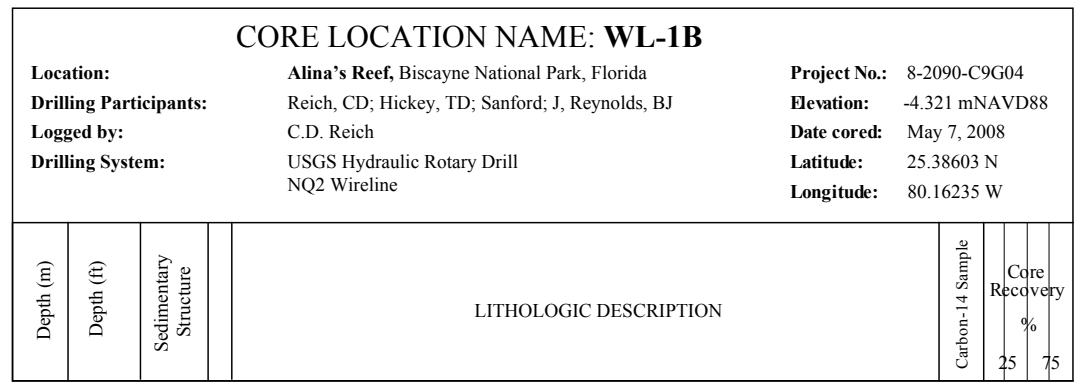

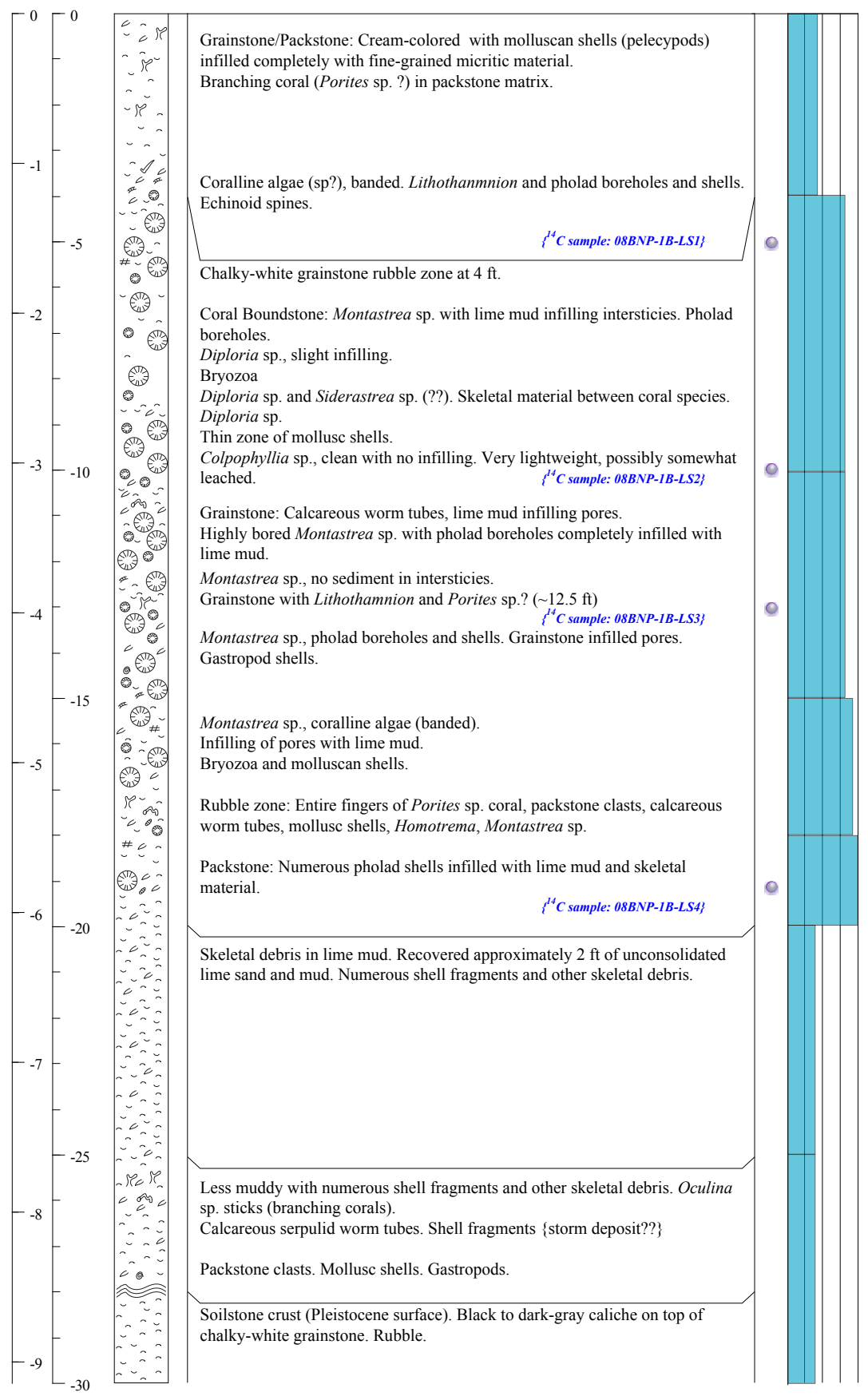

\begin{tabular}{|lll|}
\hline science for a changing world & $\begin{array}{l}\text { Company Name: } \\
\text { Project Name: } \\
\text { Location: }\end{array}$ & $\begin{array}{l}\text { Uolocene Sea Level in South Florida } \\
\text { Biscayne National Park, Florida }\end{array}$ \\
\hline
\end{tabular}

Figure B4. Core description for WL-1B. 


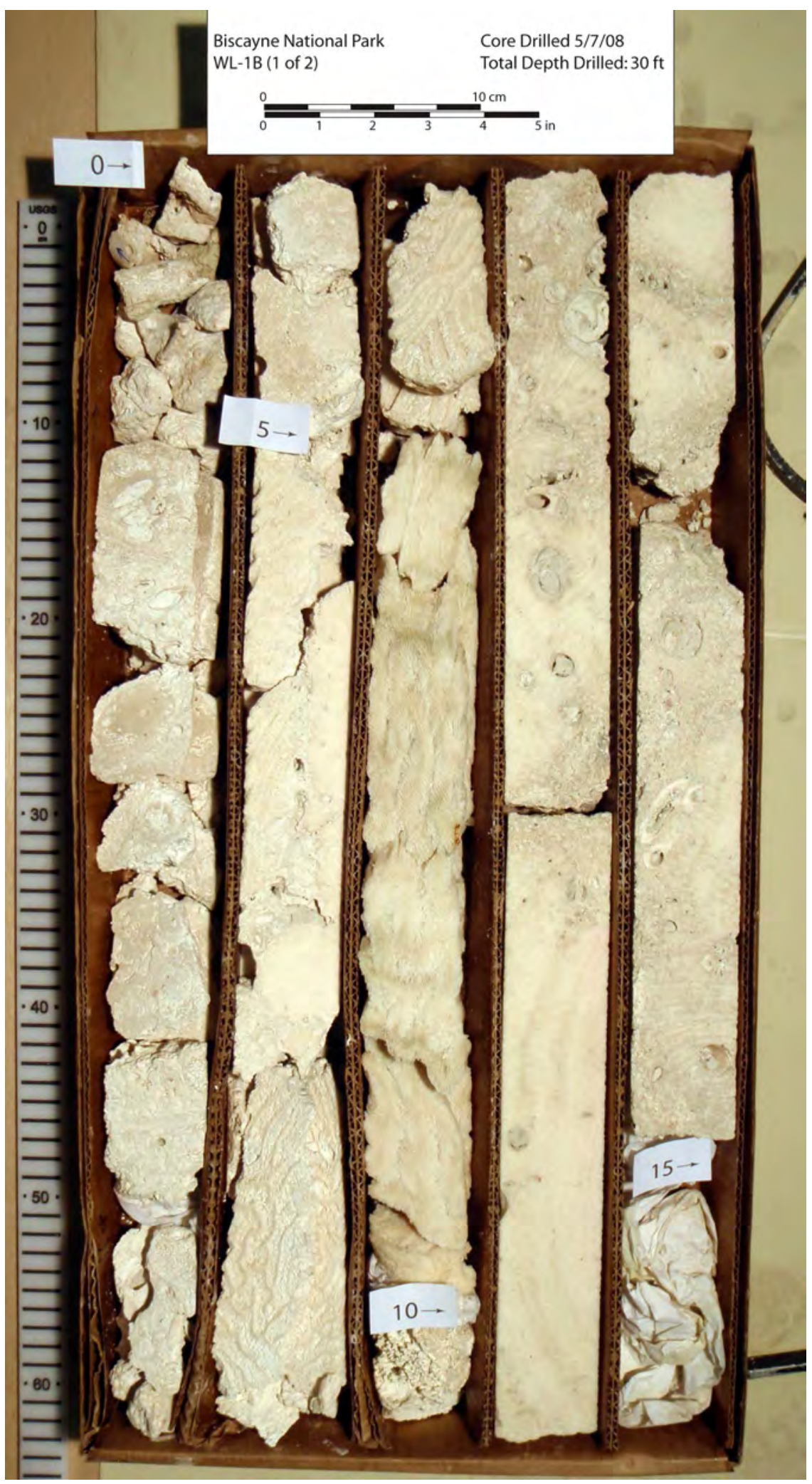

Figure B5. Core (1 of 2) collected at WL-1B (0 to $15 \mathrm{ft})$. 


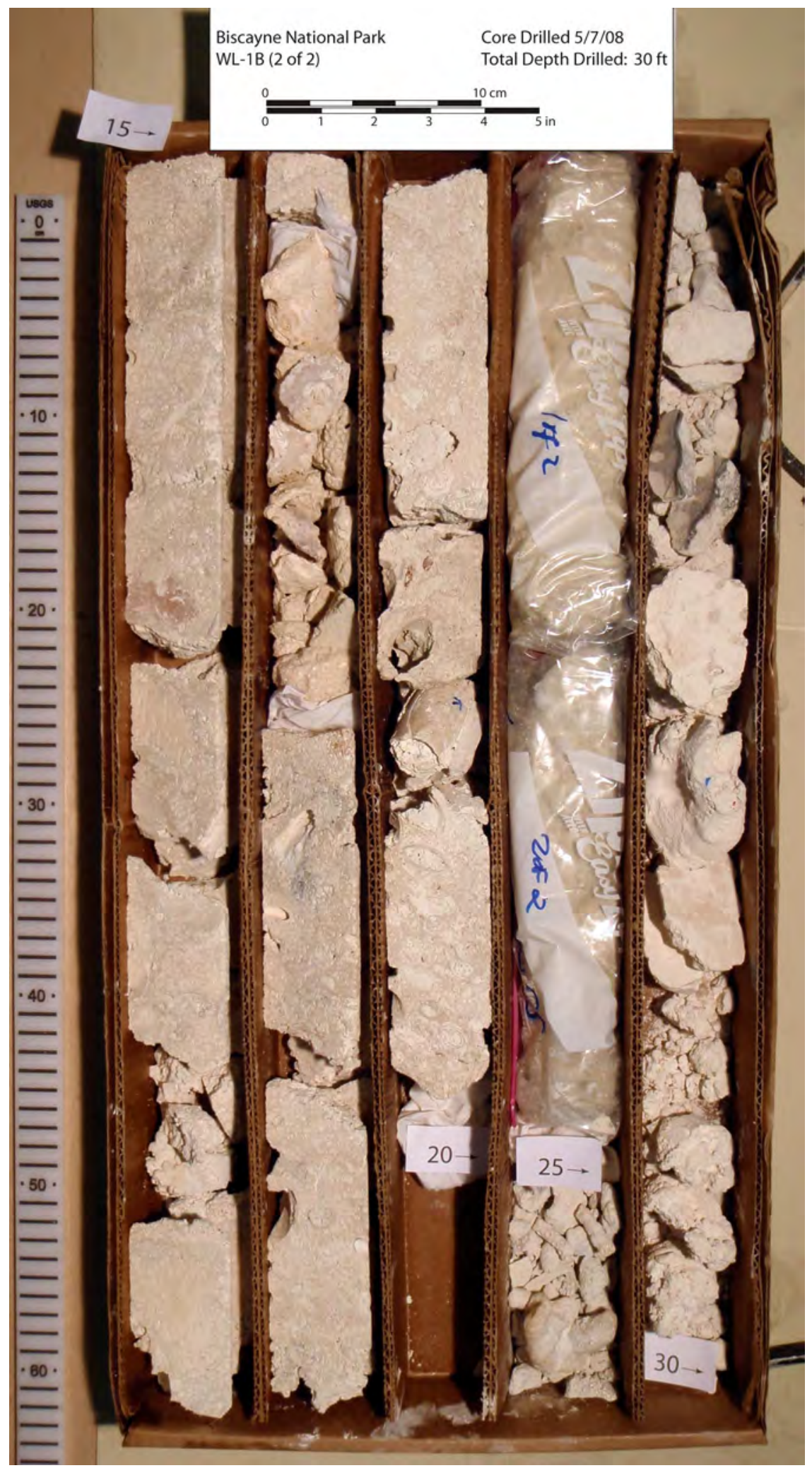

Figure B6. Core (2 of 2) collected at WL-1B (15 to $30 \mathrm{ft})$. 


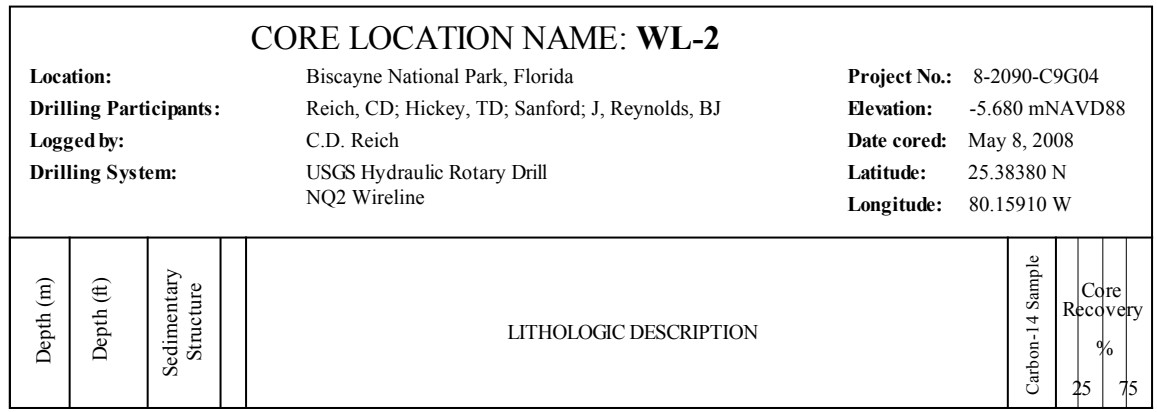

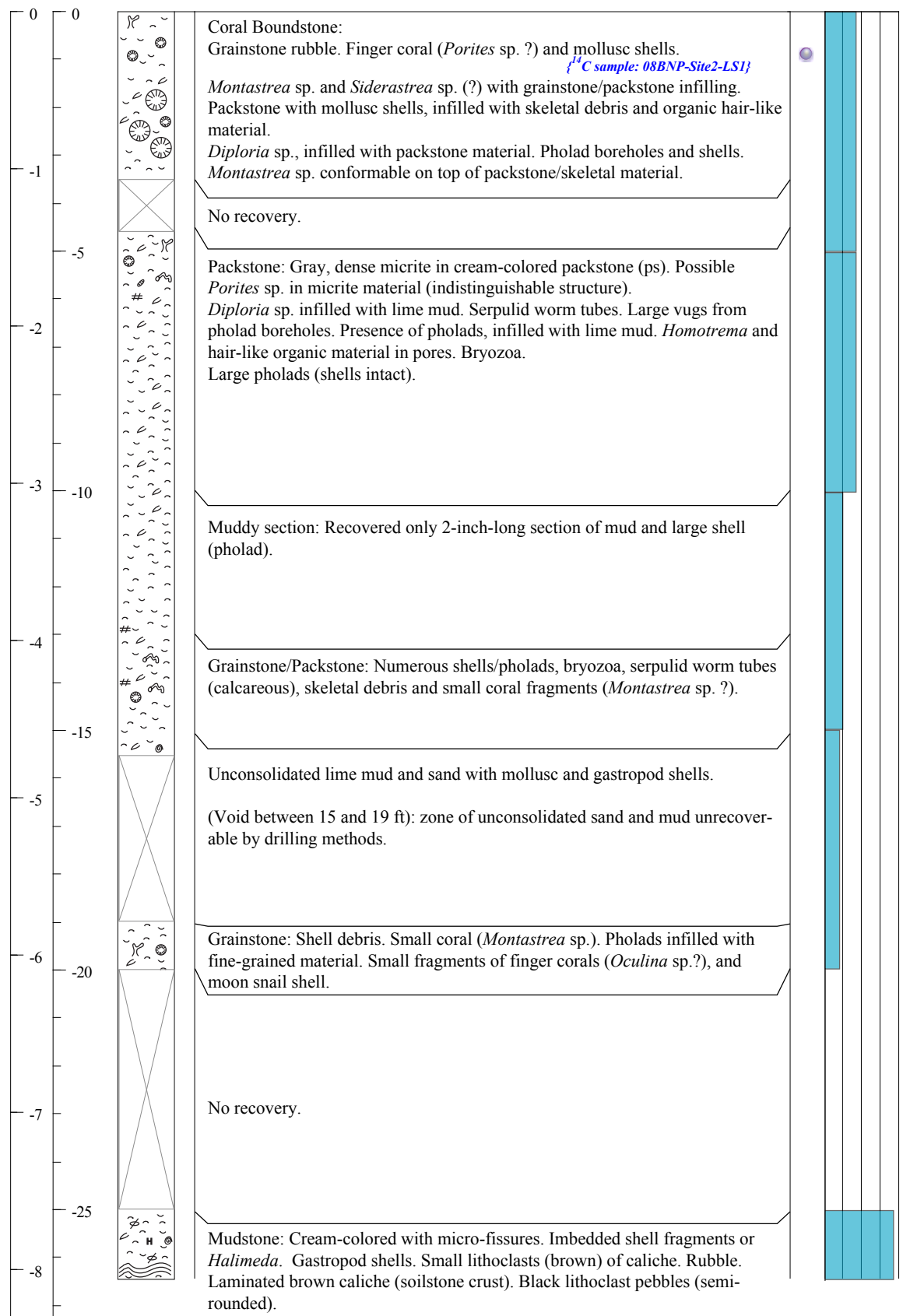

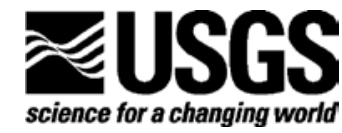
Company Name:
USGS, St. Petersburg

Figure B7. Core description for WL-2. 


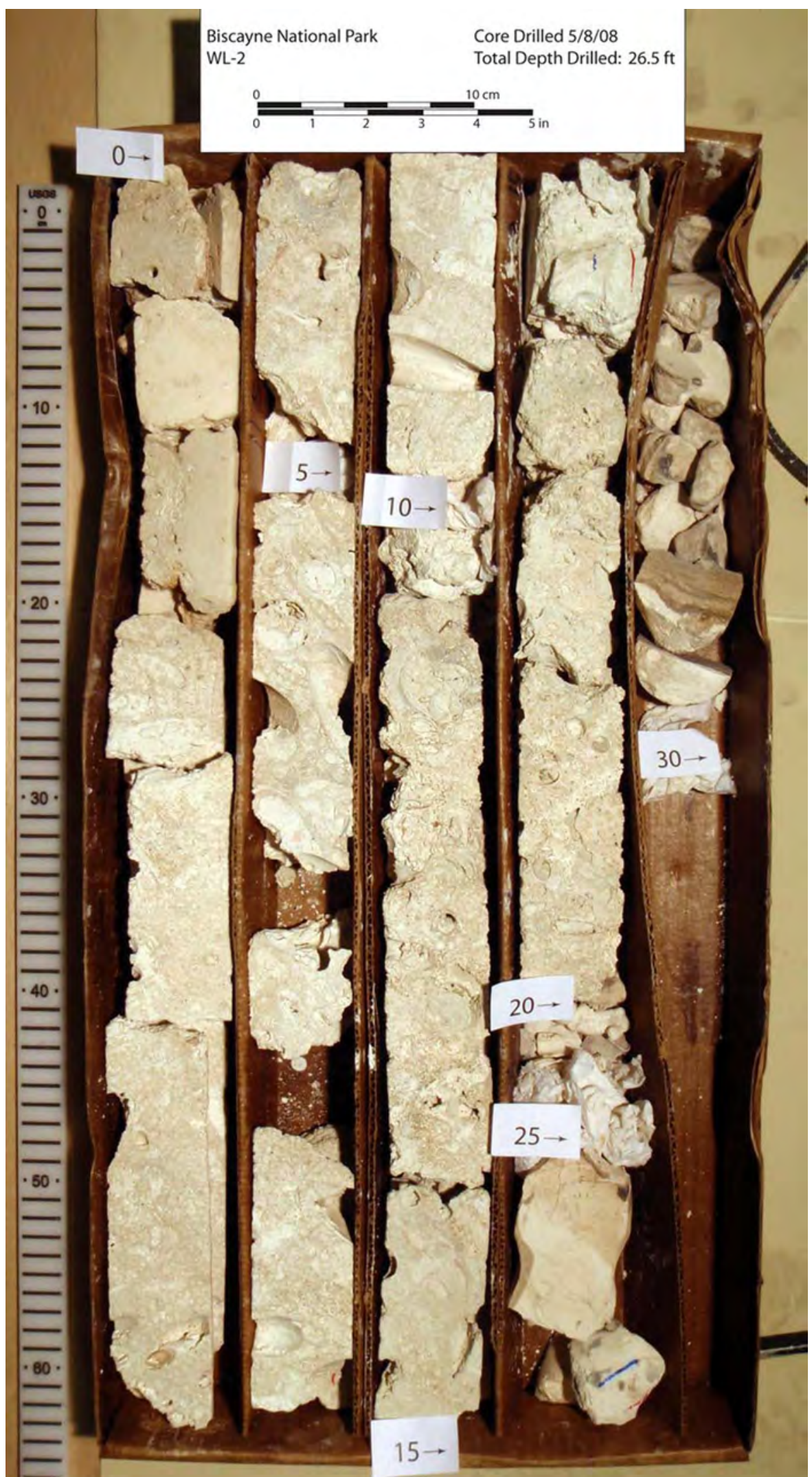

Figure B8. Core collected at WL-2 (0 to $30 \mathrm{ft}$ ). 


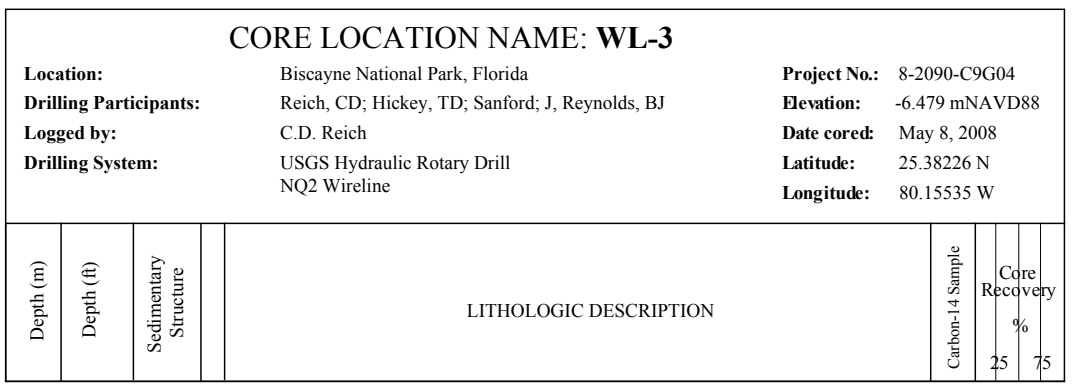

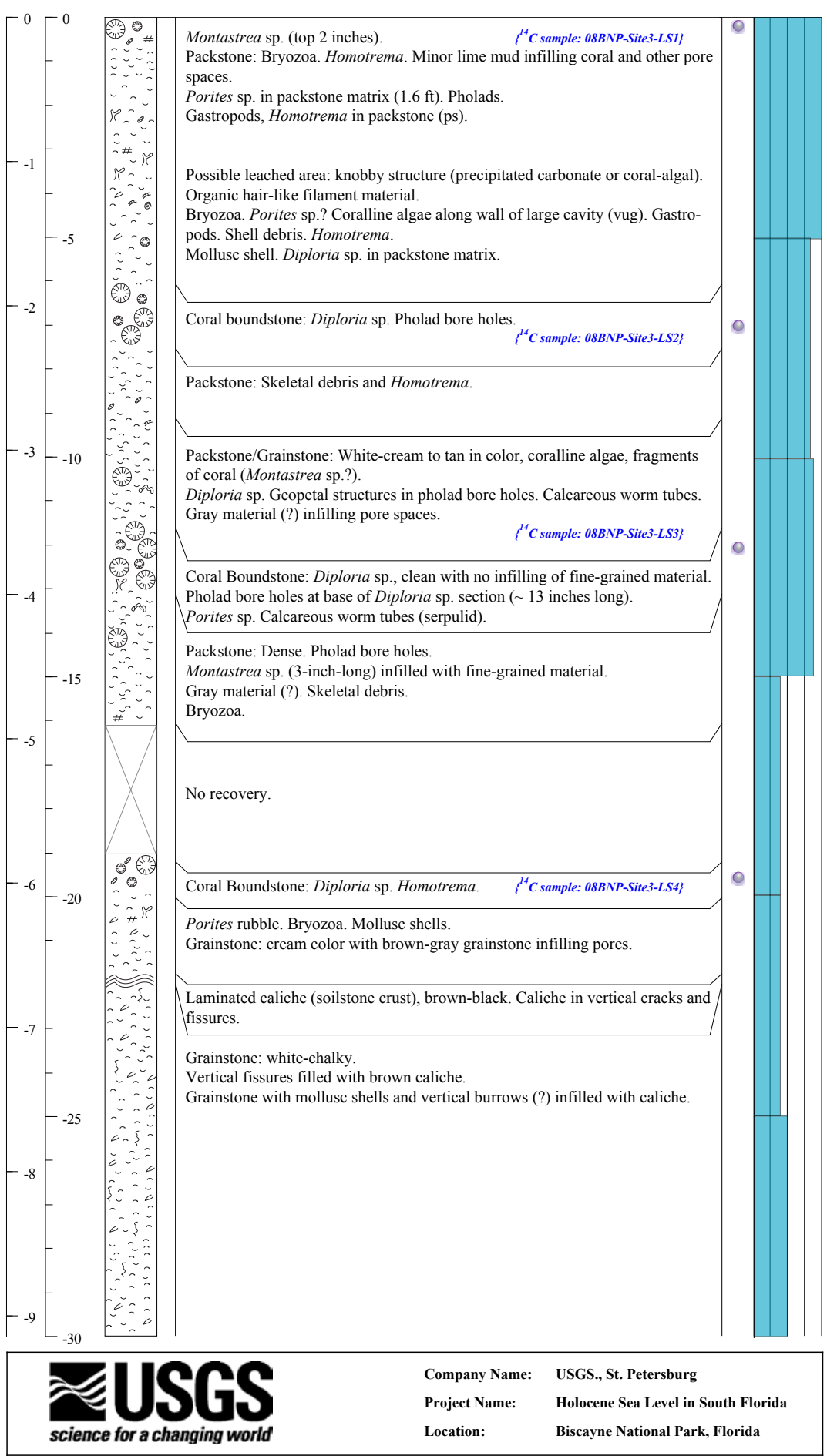

Figure B9. Core description for WL-3. 


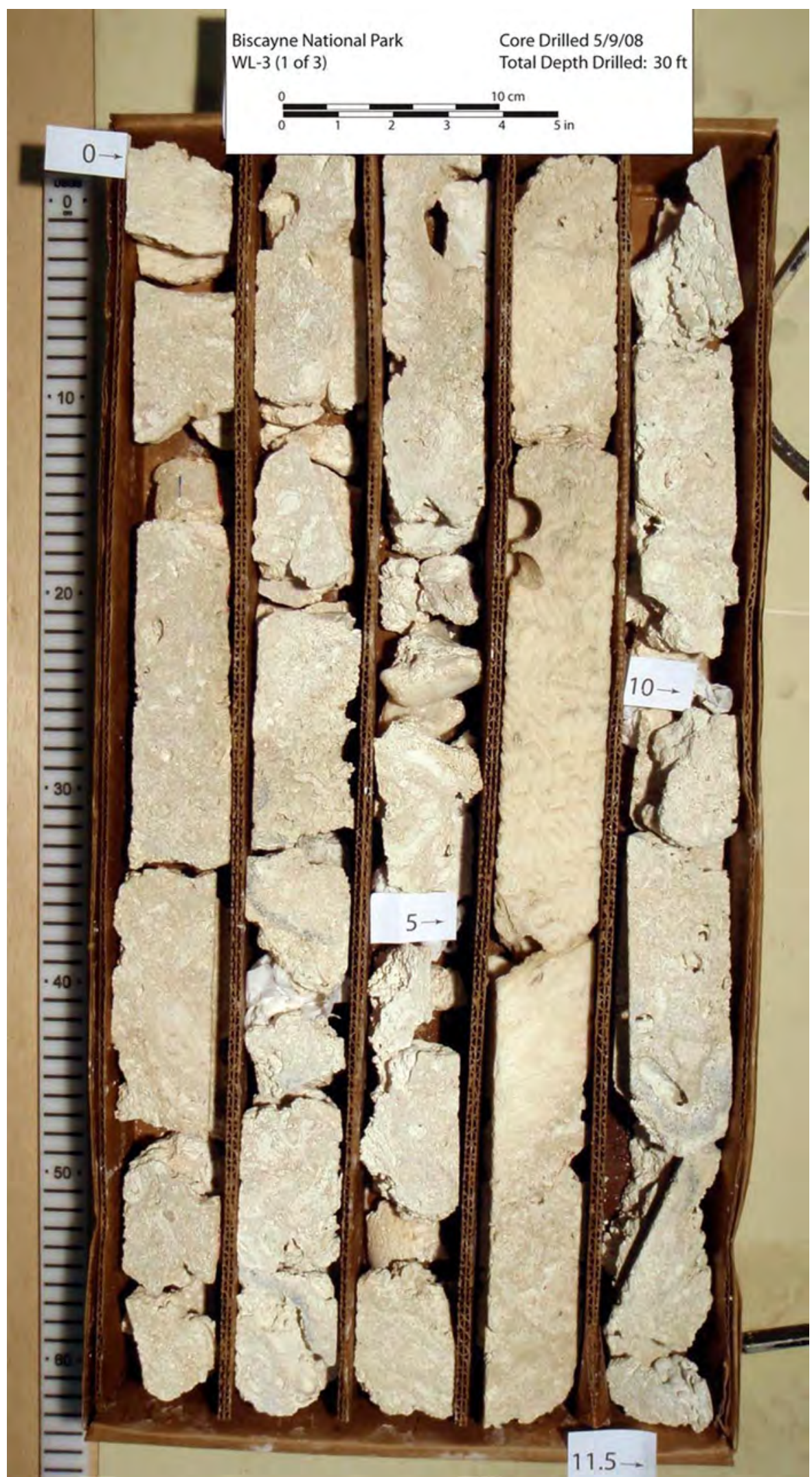

Figure B10. Core (1 of 3$)$ collected at WL-3 (0 to $11.5 \mathrm{ft})$. 


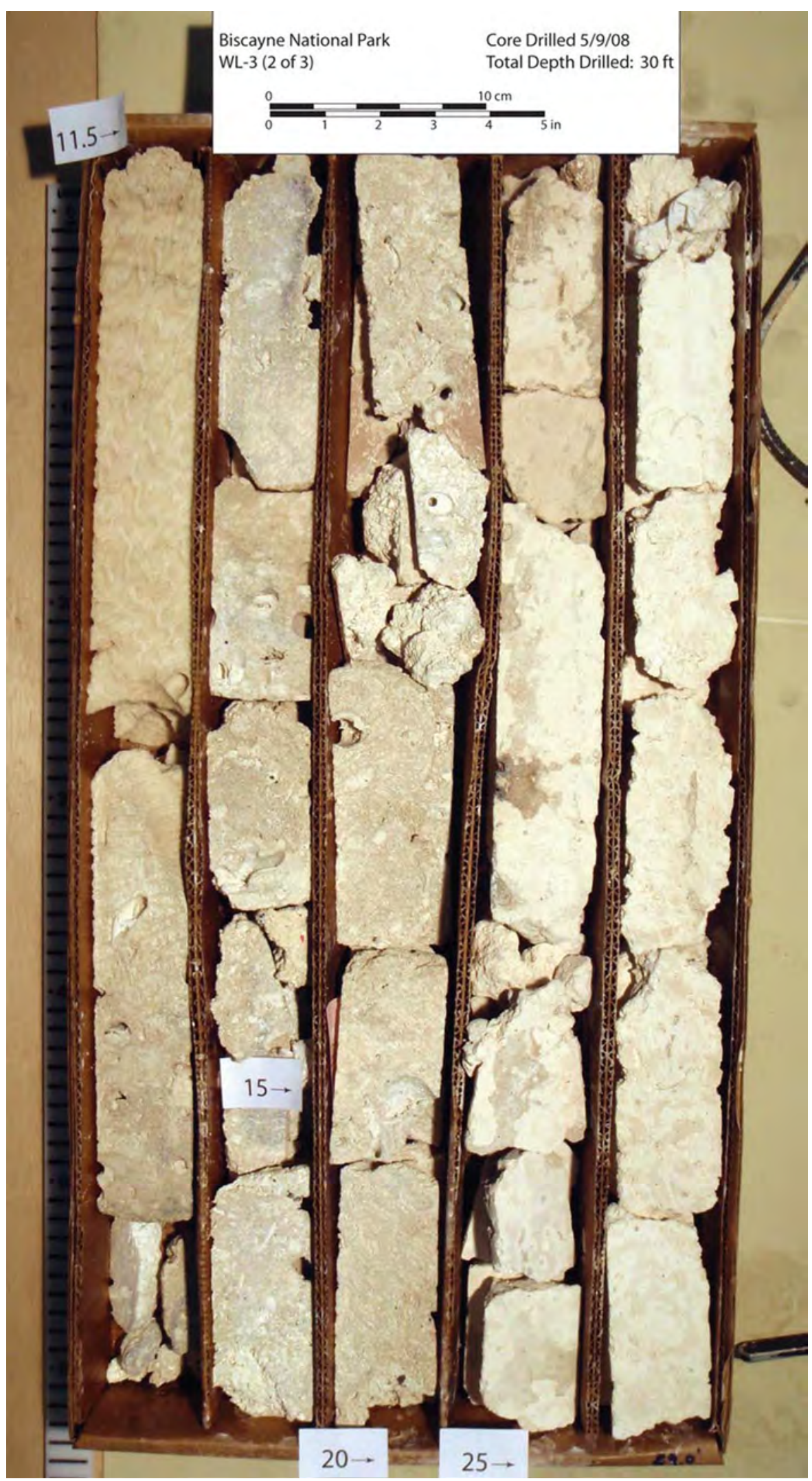

Figure B11. Core (2 of 3) collected at WL-3 (11.5 to $29 \mathrm{ft})$. 


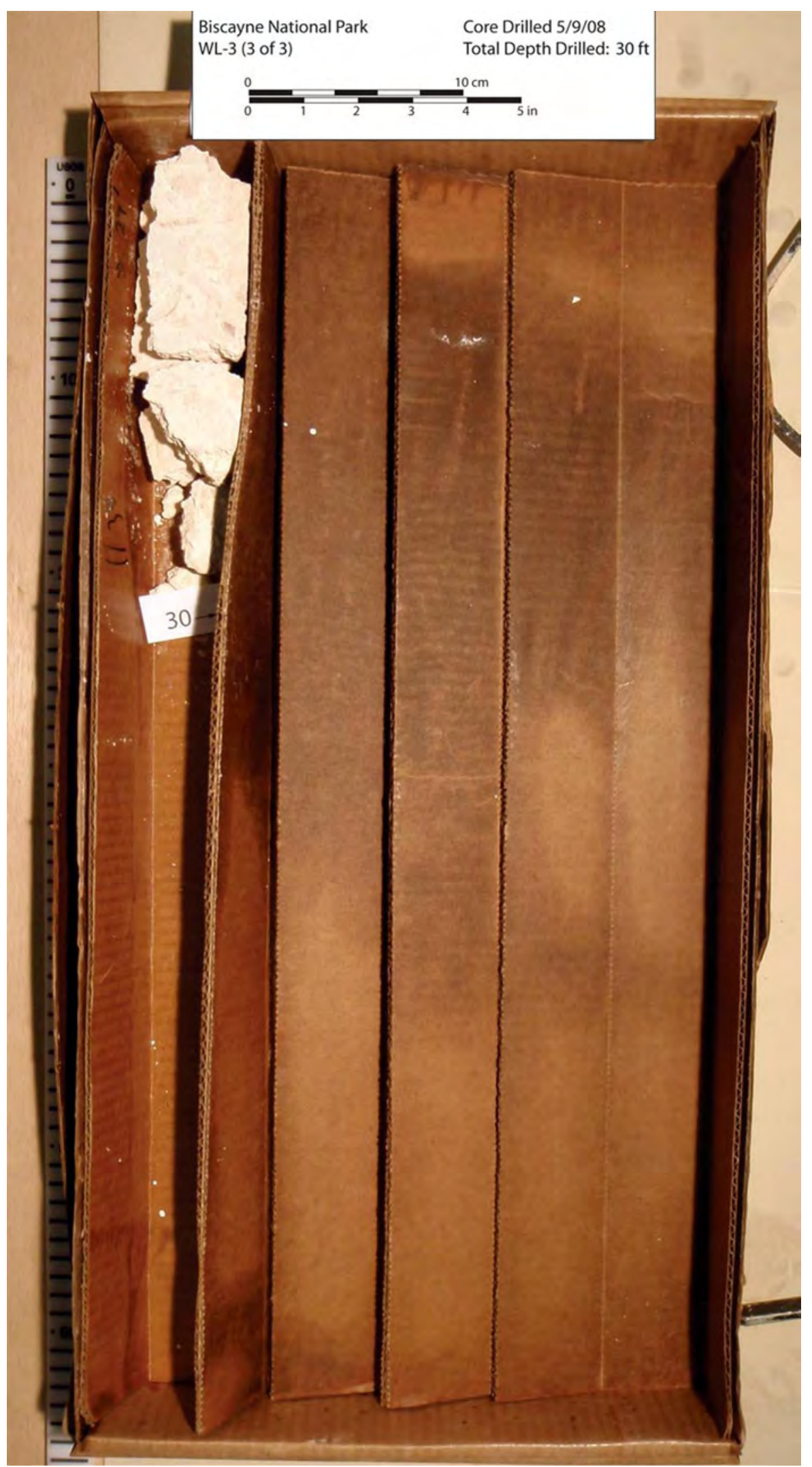

Figure B12. Core (3 of 3) collected at WL-3 (29 to $30 \mathrm{ft})$. 


\section{Prepared by:}

USGS Enterprise Publishing Network

Raleigh Publishing Service Center

3916 Sunset Ridge Road

Raleigh, NC 27607

For additional information regarding this publication, contact:

Christopher D. Reich, Geologist

St. Petersburg Science Center

600 Fourth Street South

St. Petersburg, FL 33701-4846

phone: 727-803-8747 ext. 3032

email: creich@usgs.gov

Or visit the St. Petersburg Science Center Web site at: http://coastal.er.usgs.gov/

This publication is available online at: http://pubs.usgs.gov/of/2009/1246/ 


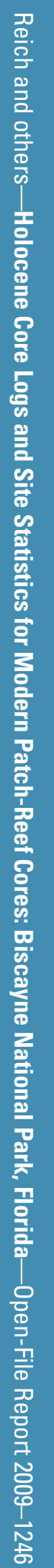

